\title{
Drivers of Management of Spider Plant (Gynandropsis gynandra) Across Different Socio-linguistic Groups in Benin and Togo
}

\author{
E. O. Dêêd Sogbohossou ${ }^{*, 1,2}$, Enoch G. Achigan-DaKo ${ }^{2}$, \\ Tinde VAn ANDEL ${ }^{1,3}$, AND M. ERIC SChranz ${ }^{1}$
}

${ }^{1}$ Biosystematics Group, Wageningen University, Wageningen, The Netherlands

${ }^{2}$ Laboratory of Genetics, Horticulture and Seed Sciences, Faculty of Agronomic Sciences, University of Abomey-Calavi, Abomey-Calavi, Republic of Benin

${ }^{3}$ Naturalis Biodiversity Center, Leiden, The Netherlands

*Corresponding author; e-mail: deedi.sogbohossou@wur.nl

\begin{abstract}
We investigated the relationships between the cultural importance of spider plant (Gynandropsis gynandra), a neglected leafy vegetable in West Africa, and the different management regimes of the species among six socio-linguistic groups in Benin and one in Togo. Semi-structured interviews were conducted with 428 respondents. Cultural significance and management indices were used to quantify the importance of the species for each respondent. In addition to food uses, G. gynandra was used to cure 42 different diseases. A regression tree analysis revealed that the cultural importance and level of management of the species were strongly associated with ethnicity, gender, and to a lesser extent to age, education, income, and land tenure. Socio-linguistic groups with similar cultural background had convergent perceptions of the cultural importance of the species and described similar management practices. An analysis of farmers' willingness to change their current management practices revealed that migration, market opportunities, and external intervention might significantly affect future management decision-making processes. We discuss community-oriented approaches to upscale the species cultivation in the region. Our study highlights how cultural importance influences current and future management intensity and illustrates how ethnobotanical research can guide research for development strategies to enact positive changes in communities' management of traditional leafy vegetables.
\end{abstract}

Nous avons étudié les relations entre l'importance culturelle du Caya blanc (Gynandropsis gynandra), un légume-feuille négligé en Afrique de l'Ouest, et les différents régimes de gestion de l'espèce au sein de six groupes socio-linguistiques au Bénin et un au Togo. Des entretiens semi-structurés ont été menés auprès de 428 informants. Des indices d'importance culturelle et de gestion ont été utilisés pour quantifier l'importance de l'espèce pour chaque informant. En plus des utilisations alimentaires, G. gynandra a été utilisé pour soigner 42 maladies différentes. Une analyse par arbre de régression a révélé que l'importance culturelle de l'espèce était fortement associée à l'ethnicité et au genre, et dans une moindre mesure à l'âge, l'instruction, le niveau de revenu et le mode de faire-valoir de la terre. Les groupes sociolinguistiques culturellement proches ont eu des perceptions convergentes de l'importance culturelle de l'espèce et décrit des pratiques de gestion similaires. Une analyse de la volonté des agriculteurs de modifier leurs pratiques de gestion actuelles a montré que la migration, les opportunités de marché et l'intervention extérieure pourraient affecter les futurs processus décisionnels de gestion. Nous avons discuté des approches axées

\footnotetext{
${ }^{1}$ Received 23 November 2017; accepted 11 July 2018; published online 14 August 2018

Electronic supplementary material The online version of this article (https://doi.org/10.1007/s12231-0189423-5) contains supplementary material, which is available to authorized users.
} 
sur la communauté pour améliorer la production de l'espèce dans la région. La présente étude souligne comment l'importance culturelle influence l'intensité de la gestion actuelle et future et illustre comment la recherche ethnobotanique peut guider les stratégies de recherche pour le développement afin de favoriser des changements positifs dans la gestion de légumes-feuilles négligés par les communautés locales.

Key Words: Neglected and underutilized species, traditional knowledge, management, ethnicity, West Africa.

Mots Clés: Espèces négligées, connaissances traditionnelles, gestion, ethnicité, Afrique de l’Ouest.

\section{Introduction}

Wild edible plants constitute an essential food source used around the world and contribute to diet diversification and livelihoods in several communities (Ong and Kim 2017; Pawera et al. 2017). New trends in nutrition and the rising popularity of functional foods led to a regain of interest for these species and documentation of their utilization (Euczaj et al. 2012; Romojaro et al. 2013). Some studies reported a decrease in the knowledge and consumption of wild edible plants associated with modernization of communities' lifestyles (Menendez-Baceta et al. 2017) and urbanization (Leal et al. 2018; Reyes-García et al. 2005). Among the Ati Negrito community in the Philippines, knowledge and use of wild edible plants was positively correlated with age, past experience of hunger, and household size but negatively affected by education and access to media and social services (Ong and Kim 2017). However, in some contexts, modernization and acculturation enriched plant knowledge and use through interaction with different communities and diversification of the sources of knowledge. Plant knowledge and use was rather greatly influenced by personal experiences, degree of interest for plants, age, and occupation (MathezStiefel and Vandebroek 2012; Quinlan and Quinlan 2007; van den Boog et al. 2017). The participation in wild food collecting also differs regionally and may vary according to the income level, age, gender, opportunities to collect wild food, and cultural factors (Schulp et al. 2014). Cruz et al. (2013) found that while knowledge about wild edible plants was related to age, their current use was not associated with age, gender or occupation. Migration patterns also play an important role in the dynamics of plant knowledge and use and induced changes vary depending on differences in social, cultural, economic, institutional, and ecological contexts between migrants' home country/ region and their host country/region (Medeiros et al. 2012). Knowledge exchange and significant cultural interactions may occur and migrant communities may adapt to the flora, knowledge, and traditions of the host country (Ceuterick et al. 2008; Volpato et al. 2009). This process is illustrated by the case of Tyrolean migrants and their descendants who migrated from Austria to Australia, Brazil, and Peru, 50, 80, and 150 years ago respectively. Investigation of their knowledge of medicinal plants revealed that in all three countries they abandoned specific medicinal plants and related practices from the original pharmacopeia when the plants were neither available nor cultivated in the country of arrival (Pirker et al. 2012). Migrants might also actively preserve the flora and knowledge from their home country or region as an attempt to conserve their cultural identity, as for example, the case of the Dominicans living in New York City (Vandebroek and Balick 2012) or the Surinamese in the Netherlands (van Andel and Westers 2010).

Associations between the body of knowledge developed by local communities and the harvesting strategies adopted have been increasingly investigated for informed conservation and management strategies of those useful plants. Typologies of plant management types take into account a gradient of complexity of practices and artificial selection (Vodouhè and Dansi 2012). González-Insuasti and Caballero (2007) described different management strategies including gathering from the wild, incipient non-selective management, incipient selective management, and occasional cultivation as a gradient of manipulation of plant resources. The intensity of management of a plant is determined not only by its biological characteristics but also by its cultural and/or economic importance and its availability (Blancas et al. 2013; González-Insuasti et al. 2008; N'Danikou et al. 2015). Many plant resources are managed in a variety of incipient forms and these forms may coexist for populations of the same species (Blancas et al. 2010; González-Insuasti and Caballero 2007). For example, local resources management decisions in the Raramuri community in Mexico were based on a culturally embedded 
understanding of ecological processes. Different management regimes including selective harvesting, pruning, and favorable environmental modifications were applied to different groups of wild edible plants to ensure their sustainable use (LaRochelle and Berkes 2003). Human cultural values and traditional ecological knowledge of plant resources are therefore crucial for making management decisions in order to ensure or increase the availability and/or quality of desired plant resources (Blancas et al. 2013). However, despite extensive ethnoecological knowledge and awareness of sustainable harvesting practices, market forces might bring communities to abusive harvesting of wild plant resources to meet both market demand and their immediate economic needs (Ghimire et al. 2004; Sundriyal and Sundriyal 2004).

González-Insuasti et al. (2011) suggested a quantitative approach to investigate the determinants of management intensity tested for 20 edible plants under different management forms within a rural community of the Tehuacan Valley, Mexico. Management forms were influenced by socio-cultural variables such as age, education, and occupation as well as food preferences. The type of land tenure was also important, as commercially important species tended to be managed in communal areas whereas non-commercial food species were managed more intensely in private areas (GonzálezInsuasti et al. 2011). Gender is also a decisive factor influencing management practices in communities where there is a gender differentiation of farm activities (Ekué et al. 2010; Vodouhè and Dansi 2012). Cruz et al. (2013) found that the degree of management of native wild edible plants in a local community in Brazil could be mainly explained by age and occupation. Younger respondents had lower motivation to tolerate wild edible plants than older ones. Farmers were also more inclined to manage the species than non-farmers. Blancas et al. (2013) developed an index to quantify management intensity of plant species based on 11 indicators related to energy invested, types of tools used, complexity of regulations and institutions, artificial selection intensity, and plant species biology. Investigation of management motives revealed that risk indicators on plant resources availability including life cycle, reproductive system, distribution, number of uses, and regulation of uses significantly influenced management intensity.

The existence of various human cultures, their distinct culinary costumes, the variable range of socio-economic situations, the differential availability, and forms of access to resources, help to understand that management of plant resources at each location depends on multiple factors that need to be analyzed particularly for species and communitarian contexts (Arellanes et al. 2013). Cross-cultural studies of plant use and management described different scenarios with emphasis on the interconnections between socio-cultural and ecological systems. Traditional communities with a strong connection with their environment and who depend on natural resources for livelihood had deeper plant knowledge and frequently used these species compared with urban communities (Monteiro et al. 2006; Soares et al. 2017). Communities sharing the same cultural background are also likely to have convergent patterns of plant knowledge and use. Exceptions arise when communities of the same socio-cultural background live in contrasting phytogeographical areas (Achigan-Dako et al. 2011). Migrant communities are obliged to adapt their management practices to the flora of their new environment and domestication may become a strategy to ensure availability of the culturally important species (Kujawska and Pardo-de-Santayana 2015; Segnon and AchiganDako 2014). Likewise, communities with different cultural backgrounds may share the same uses of wild food plants when living in the same environment (Ghorbani et al. 2012). The way complex interactions between local context, cultural values, and traditional knowledge might affect wild edible plant resources management in the future has been given less attention. Moreover, drivers of such change need to be carefully investigated to determine leverage actions and enhance sustainable utilization. A comparison of records of wild edible plants uses in Belarus between the 19th and the 21 th centuries revealed a conservation of edible fruits use but a decrease in the knowledge and use of wild edible vegetables (Łuczaj et al. 2013). Taste appreciation is likely to have played a crucial role in the preservation of some wild vegetables over time (Euczaj et al. 2013; Ong and Kim 2017). Urbanization coupled with increased knowledge exchange between different communities (Georgian and Emshwiller 2013), communities' migration and adaptation to new environments, market opportunities (Arellanes et al. 2013; Reyes-Garcia et al. 2005), education, and patterns of knowledge transmission within communities (van den Boog et al. 2017) are all factors which can affect decision-making processes related to wild edible plants management.

The current management spectrum of spider plant (Gynandropsis gynandra (L.) Briq.), a neglected 
leafy vegetable in Benin and Togo (West Africa), offers a good example to study current management intensity of the species and understand how its management and use could change in different communities to inform strategies for sustainable utilization and conservation. Spider plant is cultivated in some communities in East and West Africa (Abasse et al. 2007; Oluoch et al. 2009) as well as Asia (Arora 2014). The species is rather found wild or feral in other parts of Africa (Dovie et al. 2007; Kidane et al. 2015; Segnon and Achigan-Dako 2014). Initiatives for promoting the species in commercial farming systems are rapidly emerging, especially in East Africa (Onyango et al. 2013) as a result of increased recognition of its multiple nutritional and health benefits (Omondi et al. 2017).

The present study aims at documenting the current management practices on Gynandropsis gynandra in local communities of Benin and Togo to explore drivers for future positive change. Using quantitative ethnobotanical data, we (1) examined the variation in the traditional knowledge and management practices of G. gynandra; (2) identified factors that influenced such traditional knowledge and management practices; and (3) analyzed farmers' willingness to improve their current management practices, i.e., collectively moving the current practices to a higher management level in the process of domesticating G. gynandra. We hypothesized that (1) current management practices are shaped by factors including ethnicity, economic and cultural values of the species, and existence of local market-oriented vegetable production systems and (2) willingness to improve the species' management in the future is influenced by ethnicity and cultural importance of the species.

\section{Materials and Methods}

\section{Study Area and SAmpling Strategy}

Based on information available on $G$. gynandra distribution and use in literature (Achigan-Dako et al. 2010; Akoègninou et al. 2006) and preliminary observations made during germplasm collection missions conducted from April to June 2015 in Benin and Togo (Cleome Consortium 2016), six socio-linguistic groups were selected in Benin: the Fon (17.6\% of the country's population), Adja (8.7\%), and Holli (1.4\%) in southern Benin and Waama (1\%), Gourmantche $(0.5 \%)$, and Zerma $(0.1 \%)$ in the north (Fig. 1).
These six socio-linguistic groups use G. gynandra as a food plant and were chosen to represent the different management regimes. The Ewe, Adja, and Fon are the three most important communities of the Gbe language group (Hounkpati 1991) while the Holli belong to the Ede language group (CENALA 2003). Both Gbe and Ede linguistic groups form the Kwa language family (CENALA 2003). The Waama and the Gourmantche belong to the Gur language family (CENALA 2003). The Zerma living in Northern Benin are migrants from Southern Niger (Dosso, Tillaberi), engaged in the trade of cereals and manufactured products (Walther 2014). The Zerma belong to the Songhay language group that is considered to be unrelated to any other known language or language group (Muhammad 2016). Ewe farmers in Togo cultivate G. gynandra for commercial purposes. Thus, the Ewe community was selected as a reference group for the comparison of management practices in Benin.

From July to August 2016, semi-structured interviews were conducted with 57 to 68 respondents per socio-linguistic group, using purposive sampling (Albuquerque et al. 2014; Tongco 2007). This sampling method allowed us to select respondents who knew the species and consumed it or used to consume it in each sociolinguistic group and to obtain a reasonable compromise between sample size and available resources to conduct our study. Although our sampling was not representative of the whole community, this method was proved to be the most adequate for ethnobotanical studies that require respondents with specific qualifications for hypothesis testing (Albuquerque et al. 2014; Tongco 2007). The surveyed localities were chosen with the help of extension services agents in each municipality, while the local authorities at each site helped us establish the first contact with consumers of the species. We shared full disclosure on the nature of the research, received authorization from local authorities in each locality in Benin and Togo, explained the objectives of the study and requested prior informed consent from all participants, and ensured participants' confidentiality by anonymizing their identities in databases and publications.

\section{INTERVIEWS}

Our questionnaire (Appendix 1, Electronic Supplementary Material, ESM) contained general socio-demographic characteristics (age, gender, 


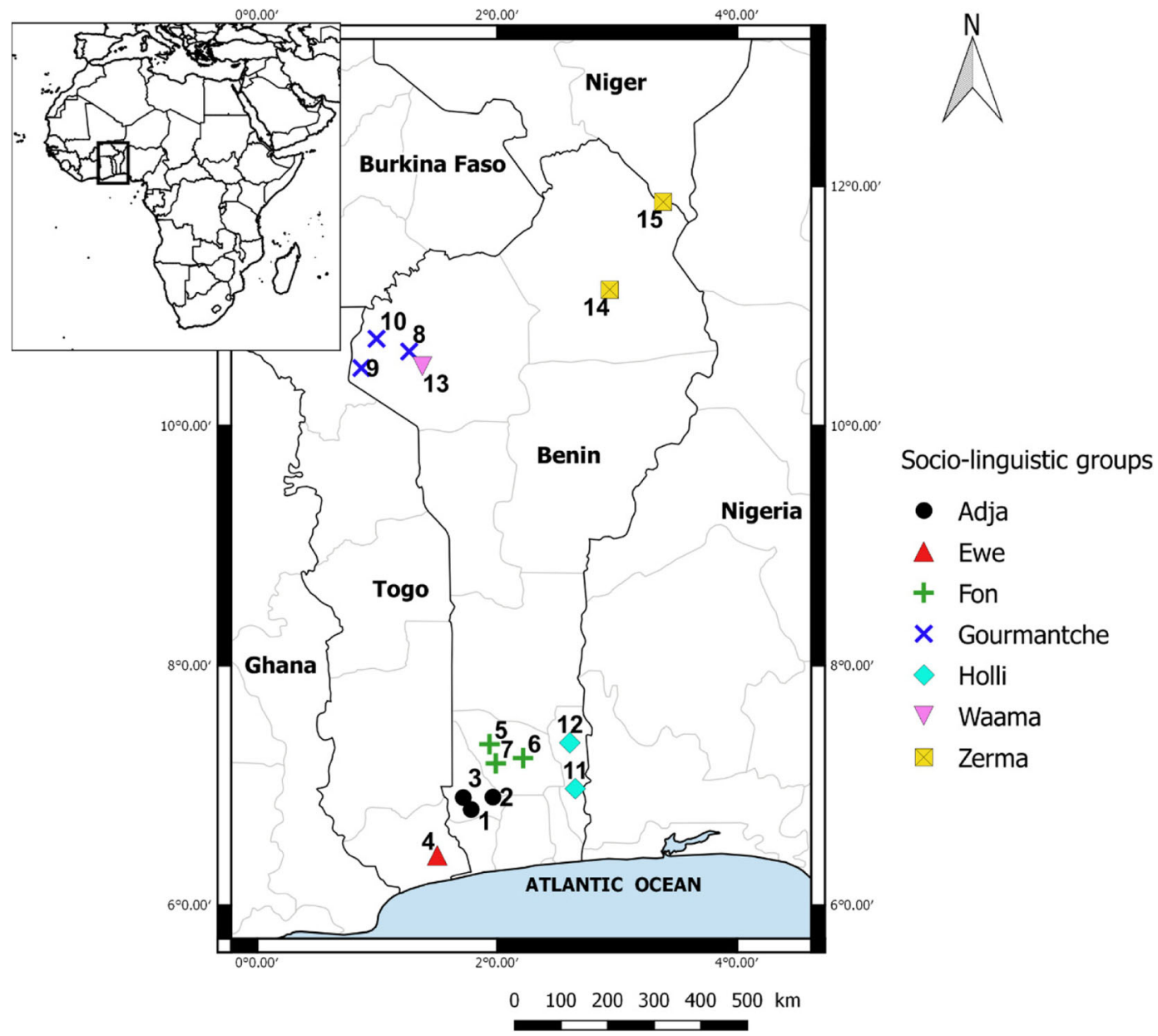

Fig. 1. Map of the surveyed districts and socio-linguistic groups interviewed in Benin and Togo. 1, Dogbo; 2, Lalo; 3, Djakotomey; 4, Vogan; 5, Djidja; 6, Za-Kpota; 7, Agbangnizoun; 8, Tanguieta; 9, Materi; 10, Cobly; 11, Pobe; 12, Ketou; 13, Toucountouna; 14, Kandi; 15, Malanville.

ethnic group, education level, occupation, number of years of local residency, area of origin (if migrant), monthly income, land ownership). Other questions were related to the economic importance of $G$. gynandra. In areas where the vegetable was sold on local markets, informants were asked about its market price. A contingent valuation was used when the species was not commercialized. Respondents were asked how much a given amount of G. gynandra would be worth in the market or for how much they would be willing to sell it. Local measurement units such as baskets and bunches were weighed to determine the average price of $G$. gynandra leaves per kilogram.

\section{Cultural Importance of the Species}

We modified the cultural significance indices (CSI) (Blancas et al. 2013; Pieroni 2001) to quantify the cultural importance of $G$. gynandra. The CSI was calculated based on 11 variables (Table 1) according the following formula:

$$
\begin{aligned}
\mathrm{CSI}= & \mathrm{RU} \times \mathrm{S} \times \mathrm{AI} \times \mathrm{FU} \times \mathrm{LC} \times \mathrm{PPU} \times \mathrm{FP} \times \mathrm{TA} \\
& \times \mathrm{H} \times \mathrm{C} \times \mathrm{MV} \times 10^{-4}
\end{aligned}
$$

The CSI was considered as a quantitative measure of the knowledge and use of $G$. gynandra. The 
TABle 1. VARIABLES AND STATES CONSIDERED TO COMPUTE THE CULTURAL SIGNIFICANCE INDEX (CSI).

\begin{tabular}{|c|c|}
\hline Variables & Modalities (scores) \\
\hline $\begin{array}{l}\text { Number of } \\
\text { reported uses } \\
\text { (RU) }\end{array}$ & Absolute number \\
\hline $\begin{array}{l}\text { Source of } \\
\text { knowledge }(S)\end{array}$ & $\begin{array}{l}\text { Parents (4); other community members (3); peo } \\
\quad \text { from different community (2); mass media }\end{array}$ \\
\hline $\begin{array}{l}\text { Perceived } \\
\text { availability of the } \\
\text { species (AI) }\end{array}$ & $\begin{array}{l}\text { Very abundant }(5) \text {; abundant }(4) \text {; moderately } \\
\text { abundant }(3) \text {; rare }(2) \text {; very rare (1) }\end{array}$ \\
\hline
\end{tabular}

Frequency of uses (FU)

Last day of consumption (LC)

Plant parts used (PPU)

Food preparation (FP)

Taste appreciation (TA)

Explanation
Number of uses cited for the species by each
informant. We included this variable as
suggested by Blancas et al. (2013). Reyes-García
et al. (2006) previously quantified the cultural
value of a species based on the number of uses
reported, the proportion of informants who
mentioned the species as useful, and the
proportion of informants who mentioned each
use of the species. In our case, the proportions of
informants are irrelevant as we computed the
values per respondent.

The source of knowledge $(S)$ indicates patterns of transmission of plant knowledge. We considered the transmission from parents to children and from other members of the same community as the best indicators of the cultural dimension of such knowledge as previously reported in literature (Lozada et al. 2006; Reyes-García et al. 2009). When several sources of knowledge were cited, the average score was considered.

Perceived availability is an important factor explaining the cultural importance of edible plants (Cruz et al. 2013; Pieroni 2001) and depends on the demand in the species. Available useful plant species tend to be more widely used than rarer ones (Albuquerque 2006; Hart et al. 2017) and their decreasing availability might trigger the domestication process if the demand cannot be satisfied (Vodouhè and Dansi 2012). In our case, the perceived availability of the species may contribute to explain patterns of knowledge and use.

Frequency of uses (FU) and last day of consumption (LC) indicate how often the respondent uses the species and how important it is in the daily diet. LC illustrates the actual use of the species and as such, complements the number of uses which only reflects informant's knowledge (de Lucena et al. 2007).

The plant parts used (PPU) (Pieroni 2001) were summed up for the respondents who used multiple organs of the species.

Cooking and processing practices are part of the cultural identity of local communities (Sansanelli et al. 2017). We attributed a higher score to processing of the species as it indicates a value addition to the plant (e.g., drying and grinding leaves for long-term storage).

The taste appreciation (Pieroni 2001) is in our case specific to each respondent and was considered as an indicator of how palatable the species is for the respondent. 
TABle 1. (Continued).

\begin{tabular}{|c|c|c|}
\hline Variables & Modalities (scores) & Explanation \\
\hline Harvest type $(\mathrm{H})$ & Opportunistic (1); dedicated (2) & $\begin{array}{l}\text { Harvesting mode was also considered an indicator } \\
\text { of importance: harvesting exclusively suggests a } \\
\text { higher cultural importance while harvesting the } \\
\text { species only when it is found while conducting } \\
\text { other activities indicates that the species is not } \\
\text { important enough to plan specific harvest } \\
\text { sessions (Blancas et al. 2013). }\end{array}$ \\
\hline $\begin{array}{l}\text { Commercialization } \\
\text { possibilities (C) }\end{array}$ & $\begin{array}{l}\text { None (0.5); existing but not exploited (1); leaves } \\
\text { sold/bought on local markets (2); leaves and } \\
\text { seeds sold/bought on local markets (3) }\end{array}$ & $\begin{array}{l}\text { We included commercialization possibilities } \\
\text { (González-Insuasti et al. 2008) to investigate } \\
\text { whether or not some respondents considered } \\
\text { selling the species or if it was already bought and } \\
\text { sold in the surveyed areas in response to a high } \\
\text { market demand. Modalities were modified to } \\
\text { take into account various situations described by } \\
\text { respondents. }\end{array}$ \\
\hline $\begin{array}{l}\text { Medicinal value } \\
\text { (MV) }\end{array}$ & $\begin{array}{l}\text { Not medicinal (1); healthy food without } \\
\text { therapeutic specification (3); medicinal (5) }\end{array}$ & $\begin{array}{l}\text { The medicinal value was used to take into account } \\
\text { the gradients of perceived "health-promoting" } \\
\text { properties. }\end{array}$ \\
\hline
\end{tabular}

11 variables were multiplied to amplify eventual variations (Pieroni 2001). Higher CSI values indicated a greater cultural importance of the species.

\section{Current Management Practices}

The management practices were described and categorized based on a management intensity index modified from Blancas et al. (2013) and GonzálezInsuasti et al. (2011). Indicators used to compute the management index are presented in Table 2. When several modalities of a variable were adopted by the same informant, the scores were summed. Individual management indices were summed to calculate the management index:

$\mathrm{MI}=\mathrm{ML}+\mathrm{AS}+\mathrm{RH}+\mathrm{PC}+\mathrm{MF}$

\section{Farmers' Intention to Improve Current Management Forms}

In order to assess farmers' intention to improve current management practices through higher investment of energy, intensive artificial selection, and land allocation (Blancas et al. 2013; GonzálezInsuasti et al. 2008), the interview included the following questions: are you satisfied with your current level of exploitation of G. gynandra? If not, what would you like to improve and how? What are the perceived constraints related to the implementation of your decisions? These questions allowed better understanding of the motivation underlying farmers' intentions to modify their management schemes in the future. In order to avoid the willingness to please biasing farmers' responses, it was well explained to them that we would not provide a reward in kind or in cash in response to their motivation to cultivate the species. Social desirability bias may lead to a tendency to provide positive answers to environmental questions, especially in studies related to behavioral intention (Floress et al. 2018). Information provided by farmers was used to compute an expected management scheme based on management forms typology adapted from González-Insuasti et al. (2008). Five steps were identified including: simple collection with no selection (1); tolerance, protection, or promotion without selection (2); transplantation of selected spontaneous individuals (3); rain-fed cultivation (4); and intensive irrigated cultivation all year round (5).

\section{Data ANALYsis}

The seven socio-linguistic groups were compared for their number of reported uses and the frequencies of uses of the species based on Kruskal-Wallis 
TABLE 2. VARIABLES USED TO ESTIMATE THE MANAGEMENT INTENSITY INDEX.

\begin{tabular}{|c|c|c|}
\hline Variables & Categories (scores) & Explanation \\
\hline $\begin{array}{l}\text { Maintenance } \\
\text { labors (ML) }\end{array}$ & $\begin{array}{l}\text { Cleaning or weeding (1); grooves water } \\
\text { penetration (1); soil tillage (1); removing dead } \\
\text { or diseased plants (1); fertilization (1); irrigation } \\
\text { (1); fumigation with pesticides (1); fences (1); } \\
\text { other dissuasive measures (1) }\end{array}$ & $\begin{array}{l}\text { Maintenance practices on managed plots as } \\
\text { suggested by Blancas et al. (2013). Only the } \\
\text { modalities cited by our respondents are listed } \\
\text { here. }\end{array}$ \\
\hline $\begin{array}{l}\text { Artificial selection } \\
\quad \text { (AS) }\end{array}$ & $\begin{array}{l}\text { Odor (1); leaf form (1); leaf color (1); stem color } \\
\text { (1); leaf size (1); phenological differences (1); } \\
\text { texture (1) }\end{array}$ & $\begin{array}{l}\text { Criteria mentioned for selection of particular } \\
\text { variants on managed plots for leaf/seed } \\
\text { harvesting and propagation. }\end{array}$ \\
\hline $\begin{array}{l}\text { Reaction to } \\
\text { harvest without } \\
\text { permission } \\
\text { (RH) }\end{array}$ & $\begin{array}{l}\text { No reaction }(0) \text {; yes, admonition applies }(1) \text {; yes, } \\
\text { applies monetary penalty }(2) \text {; yes, complaints to } \\
\text { authorities (3) }\end{array}$ & $\begin{array}{l}\text { Indicates how important the managed plots are for } \\
\text { respondents. Adapted from the variable } \\
\text { "collective regulation" (Blancas et al. 2013) to } \\
\text { assess the rules and agreements for accessing } \\
\text { and protecting plant resources. The modalities } \\
\text { we used are the ones cited by the respondents. }\end{array}$ \\
\hline $\begin{array}{l}\text { Proximity to } \\
\text { collection/- } \\
\text { cultivation sites } \\
\text { (PC) }\end{array}$ & $\begin{array}{l}\text { More than } 5 \mathrm{~km}(1) \text {; up to } 5 \mathrm{~km} \mathrm{(2);} \mathrm{up} \mathrm{to} 1 \mathrm{~km} \\
\text { (3); less than } 100 \mathrm{~m} \mathrm{(4)}\end{array}$ & $\begin{array}{l}\text { Distance from the respondent's house to } \\
\text { collection/cultivation site provides an } \\
\text { indication of the importance of the resource } \\
\text { (Blancas et al. 2013) and an indication of } \\
\text { management intensity. We gave a higher value } \\
\text { to closer sites as most respondents explained } \\
\text { that spider plant is a seasonal vegetable that } \\
\text { grows better on fertile plots near houses and can } \\
\text { be more easily managed and harvested. The } \\
\text { species requires intensive management over a } \\
\text { short period of time and could also become } \\
\text { invasive if grown in the fields. }\end{array}$ \\
\hline $\begin{array}{l}\text { Management } \\
\text { forms (MF) }\end{array}$ & $\begin{array}{l}\text { Simple collection from the wild with no particular } \\
\text { selection (1); tolerance, protection or } \\
\text { promotion of wild plants without selection (2); } \\
\text { transplantation of selected wild individuals to } \\
\text { gardens (3); rain-fed cultivation (4); intensive } \\
\text { irrigated cultivation all year round (5) }\end{array}$ & $\begin{array}{l}\text { Adapted from González-Insuasti et al. (2008) and } \\
\text { Blancas et al. (2013) to reflect the different } \\
\text { situations observed in the case of spider plant in } \\
\text { the surveyed areas. }\end{array}$ \\
\hline
\end{tabular}

tests. A regression tree analysis was performed using the R packages "tree" (Ripley 2016) and "maptree" (White and Gramacy 2012) to predict the variation in cultural significance index based on both quantitative and qualitative socio-demographic variables. The most significant variables among the dependent variables gender, age, education level, ethnicity, land tenure, land area, and level of income were selected. A generalized linear model with Poisson distribution allowed us to investigate the sociodemographic factors influencing the management intensity in each community. The deviance explained by the model $\left(D^{2}\right)$ was determined using the R package "modEvA" (Barbosa et al. 2016). As ethnicity was the main factor explaining the variation in the CSI and the management intensity, a principal component analysis was performed using the components of the CSI, the management intensity, and the economic value of the species to better describe the characteristics of the socio-linguistic groups. The Kendall's rank correlation $(\tau)$ was used to test the association between current and expected management regimes. To model the projected changes in management practices according to time (current and expected management forms) and socio-linguistic groups, a generalized estimating equation was fitted to the management forms [simple collection with no selection (1); tolerance, protection, or promotion without selection (2); transplantation of selected spontaneous individuals (3); rain-fed cultivation (4); and intensive irrigated cultivation all year round (5)]. Generalized estimating equations are commonly used in epidemiology and social sciences for multivariate logistic regression of 
ordinal longitudinal outcome variables (Nooraee et al. 2014; Parsons et al. 2009).

\section{Results}

\section{Characteristics OF Respondents}

Women represented $72.0 \%$ of the respondents and were dominant across all socio-linguistic groups except for the Ewe, of which $73.0 \%$ of respondents were male (Table 3). G. gynandra users were between 14 and 90 years old, with an average age of $44.9 \pm 15.7$ years. A high proportion of the Beninese respondents were illiterate $(73.0 \%)$, while for the Ewe ethnic group in Togo, this was only $33.0 \%$. Literate male producers dominated the G. gynandra production system in the Ewe community, while female illiterate producers were more involved in wild harvesting and home gardening. The main occupation of all respondents was farming and/or trading agricultural products. Landowners represented $66.0 \%$ of the respondents, except in the Ewe group, where most of the market gardeners leased their land (62.0\%).

\section{KNOWLEDGE AND Diversity OF USES OF G. GYNANDRA}

Gynandropsis gynandra was used by all sociolinguistic groups as food (100.0\% of respondents). Medicinal uses were mentioned by $50.7 \%$ of respondents including $80 \%$ of the Adja and Zerma, $56 \%$ of the Fon, $34 \%$ of the Gourmantche, $25 \%$ of the Holli and Ewe, and 15\% of the Waama. Spiritual uses of the species were mentioned by less than $5.0 \%$ of respondents in all groups, except for the Gourmantche and Waama communities who did not mention these uses at all. The number of reported uses varied significantly among the groups (Kruskal-Wallis $\chi^{2}=124.6, \mathrm{df}=6$, $p<0.001)$. The highest number of uses was reported by Zerma respondents $(3.2 \pm 1.5)$. The Ewe (1.7 \pm 0.8$)$, Gourmantche (1.5 \pm 0.8$)$, Holli $(1.4 \pm 0.6)$ and Waama $(1.3 \pm 0.7)$ stated the lowest number of uses.

In addition to food, $G$. gynandra was used to cure 42 different diseases, classified in 12 disease categories according to the International Classification of Diseases and related health problems (WHO 2016) (Appendix 2, ESM). General symptoms and signs not elsewhere classified were grouped in "general health" category. Most of the Adja (81.0\%) and

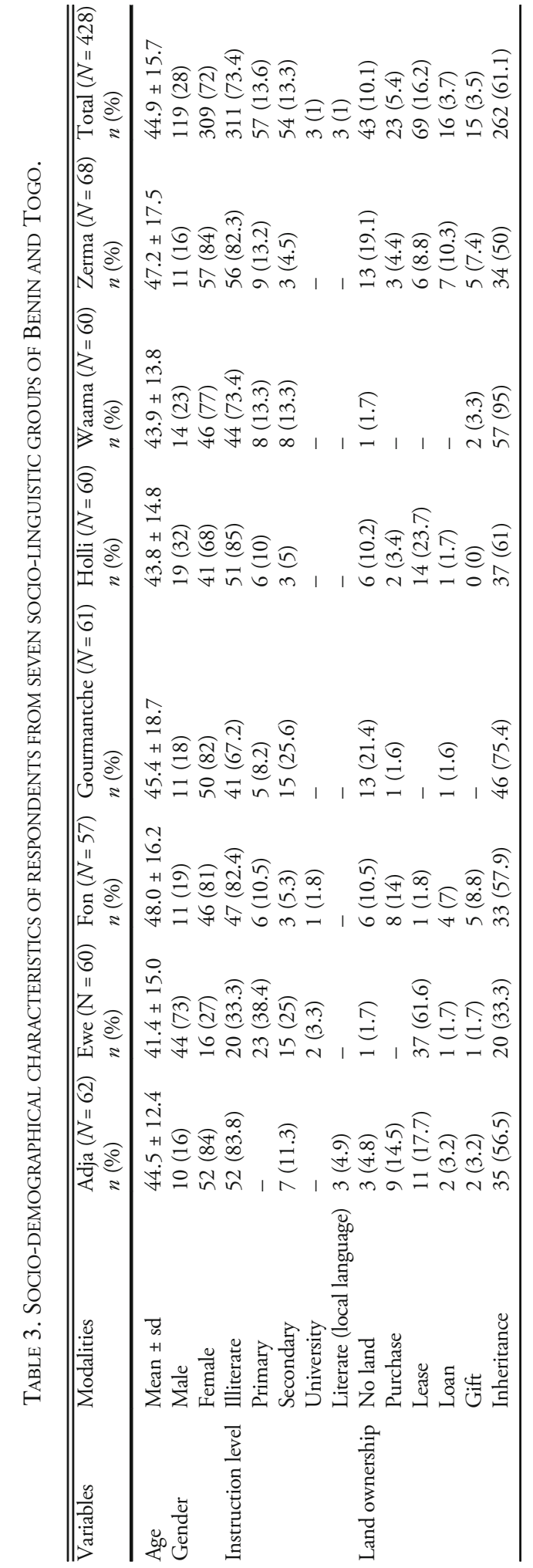


Zerma (81.0\%) respondents were aware of the medicinal uses of the species followed by the Fon (56.0\%). Only $9.0 \%$ of the Waama reported medicinal uses for the species. The most cited diseases treated with G. gynandra included malaria, headache, earache, anemia, stomachache, and malnutrition. The citation frequency of medicinal uses per disease category and socio-linguistic group are presented in Fig. 2. The categories of diseases cured and their relative importance varied across the communities. Most respondents (88\%) obtained their knowledge on $G$. gynandra uses from their parents, $7 \%$ from community members other than their parents, and 5\% from people from other communities. Among the Fon respondents, 61\% received their knowledge from their parents, $28 \%$ from community members other than their parents, and $10 \%$ from people from other communities.

\section{Factors Influencing Cultural Importance OF GYNANDROPSIS GYNANDRA}

The regression tree of the cultural significance index based on the respondents' socio-economic characteristics explained $37.1 \%$ of deviance in the cultural significance index and revealed that ethnicity was the main factor explaining the cultural importance attributed to the species $(19.3 \%$ of deviance) (Fig. 3). The splits based on other variables resulted in much lower deviance $(<4 \%)$ and therefore poorly contributed to explaining the variation in the index. The socio-linguistic groups were split into two categories: the Adja and Ewe who gave a higher cultural importance to the species were in the first category and other socio-linguistic groups in the second.

Among the Adja and Ewe, the species had a higher cultural importance for older respondents ( $\geq 57$ years) than younger respondents ( $<57$ years). Moreover, the older Ewe respondents had a CSI twice lower than their Adja counterparts. Among younger Adja and Ewe respondents, land tenure, education, and income were also important factors of differentiation (Fig. 3). Respondents who inherited family land or had no access to land gave a higher cultural importance to $G$. gynandra than those who bought or leased the land (mostly Ewe market gardeners). Non-schooled respondents and those who only attended primary school had also a higher CSI than respondents with higher education levels. In this latter category, respondents with low monthly incomes (less than 50 USD) had a higher CSI than those with higher monthly income.
Among the other socio-linguistic groups, most of the respondents $(85.0 \%)$ had low monthly income (less than 140 USD) and fell into one category with a low CSI. Among respondents with higher income (only 15.0\%), older respondents (> 41 years) had a higher CSI than younger ones. The older Fon, Gourmantche, and Holli respondents had a lower CSI than their Waama and Zerma counterparts.

\section{Variation In the Management InTENSITy, Cultural and ECONOMIC IMPORTANCE OF \\ G. GYNANDRA}

Four management regimes of $G$. gynandra were observed during the survey: (1) wild collection with no selection; (2) tolerance, protection, or promotion of plants around houses; (3) rain-fed cultivation in home gardens; and (4) intensive irrigated cultivation all year round. The significant factors explaining the variation in management intensity were ethnicity $\left(D^{2}=65.9 \%, p<0.001\right)$ and land tenure $\left(D^{2}=\right.$ $17.6 \%, p<0.05)$.

The species was intensively cultivated by Ewe market gardeners in southern Togo $(96.0 \%$ of Ewe respondents; management intensity index (MI), 14.9 \pm 1.4 ) (Fig. 4), where the price of the leaves varied between 0.25 USD per kilogram in the rainy season and $1.1 \mathrm{USD} / \mathrm{kg}$ in the dry season (1 $\mathrm{USD}=590 \mathrm{~F}$ CFA on average, July 2016). Seeds were also sold on local markets; prices varied from 5 to $16.7 \mathrm{USD} / \mathrm{kg}$, depending on the season. Rain-fed cultivation in home gardens was common among the Adja (93.0\% of respondents; MI, $11.0 \pm 2.7)$. Leaves were sold in bunches with a price that varied between 0.2 and 0.5 USD $/ \mathrm{kg}$. Seeds were occasionally sold but most of the farmers spared some of their own plants to harvest the seeds. The Gourmantche (90.2\%; MI, $4.2 \pm 1.3$ ) and the Fon (80.7\%; MI, $4.1 \pm 3.1)$ mainly harvested the plant in the wild at the beginning of the rainy season along roadsides or in fallow lands. Among Waama people, simple collection (46.7\%) and tolerance or protection of spontaneous populations (48.3\%) were the most common management practices (MI, 5.7 \pm 2.5 ). Simple collection in the wild $(63.3 \%)$ and rain-fed cultivation $(23.3 \%)$ were the dominant management practices among the Holli (MI, $4.8 \pm 2.9$ ). Our Zerma respondents pointed out that as they recently migrated from Niger to Northern Benin, they had limited access to agricultural land. They said that G. gynandra was not popular among the other socio-linguistic groups living near them in northern Benin. Therefore, 


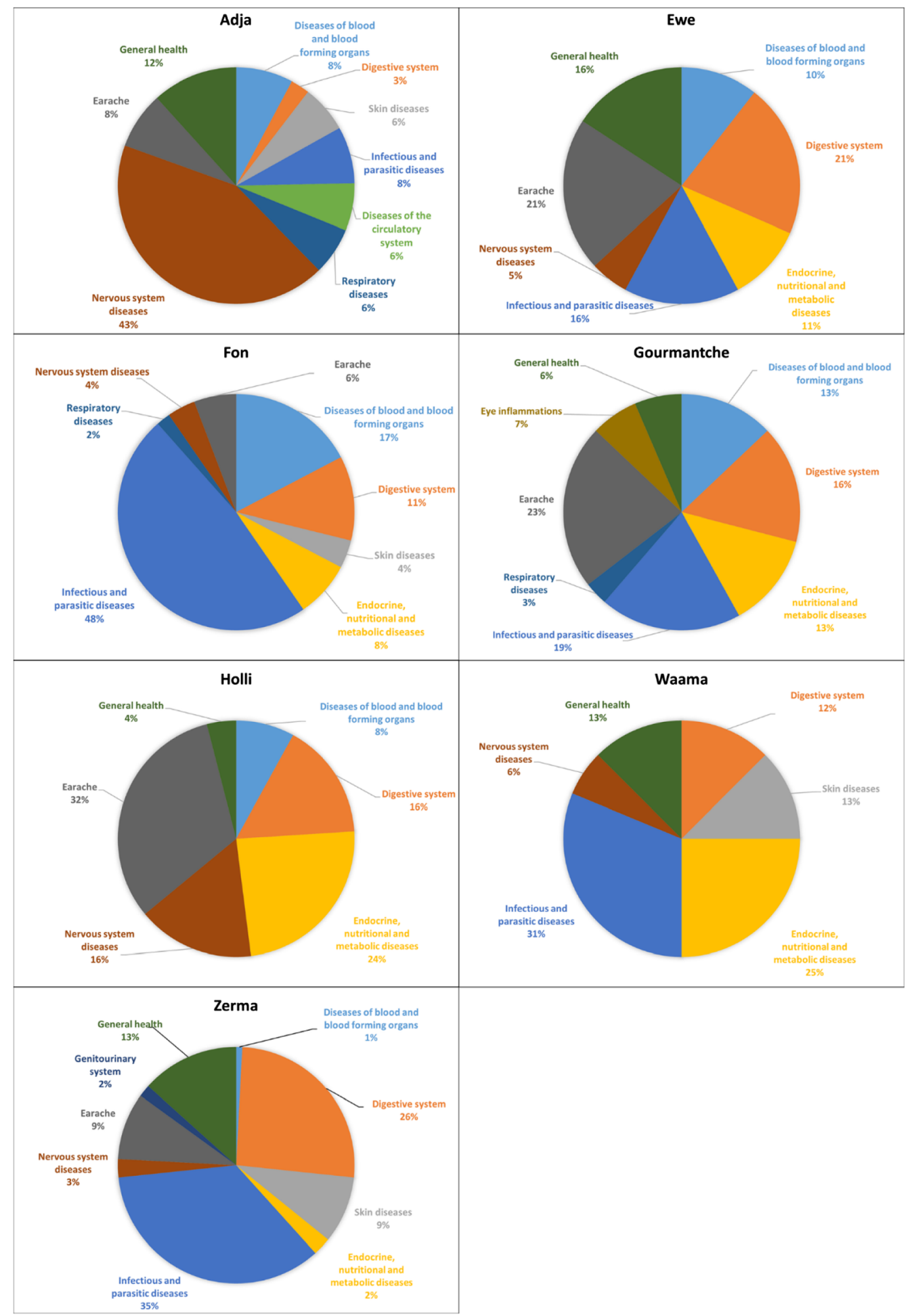

Fig. 2. Frequency of citations of categories of diseases treated with Gynandropsis gynandra in each socio-linguistic group. 


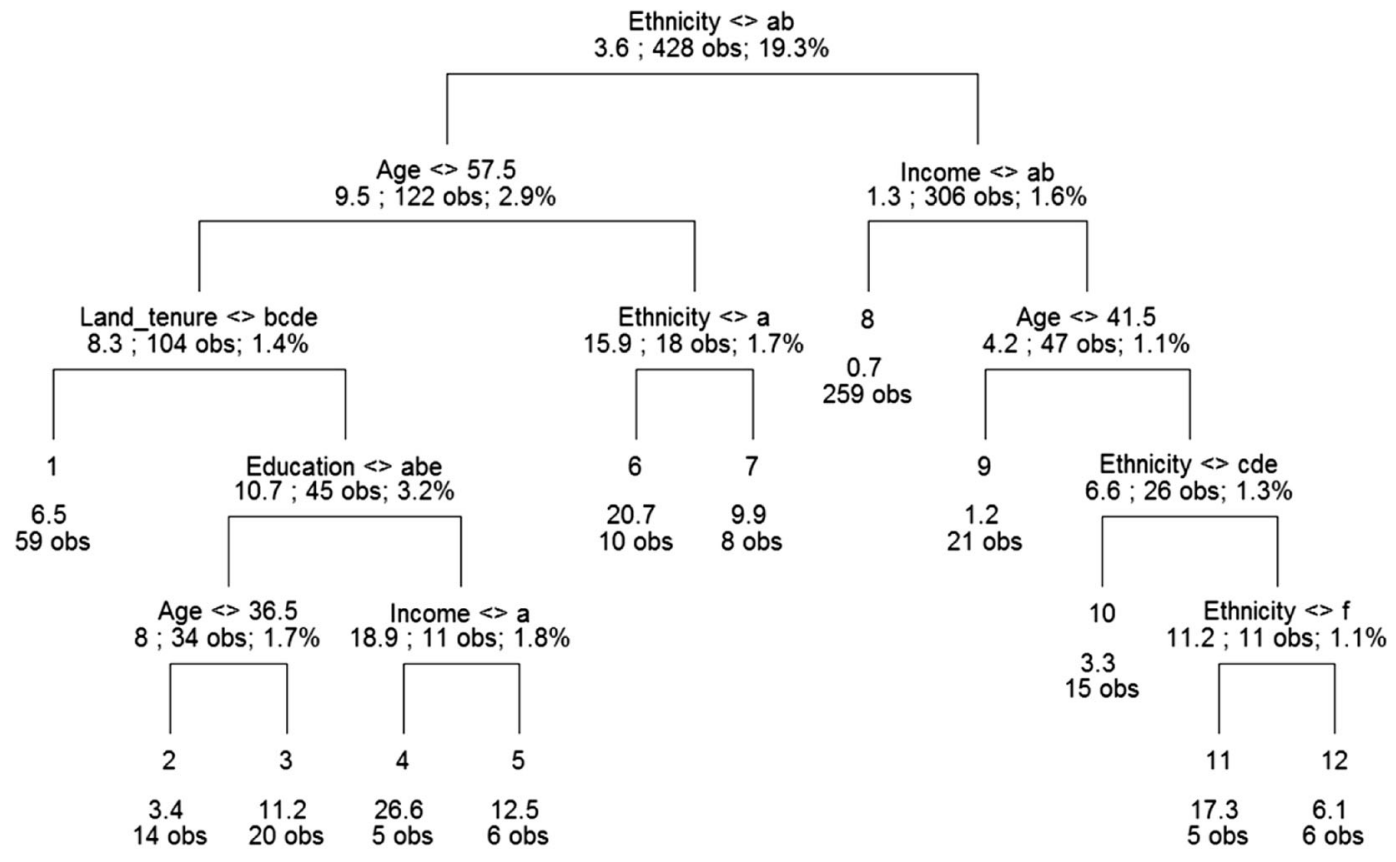

Total deviance explained $=37.1 \%$

Fig. 3. Regression tree of cultural significance index as a function of demographic variables for use of Gynandropsis gynandra. Terminal nodes display from top to bottom: terminal node number, average CSI for the subsample, and the number of observations in the subsample. Categorical predictors include: ethnicity ( $\mathrm{a}=$ Adja; $\mathrm{b}=\mathrm{Ewe} ; \mathrm{c}=\mathrm{Fon} ; \mathrm{d}=$ Gourmantche; $\mathrm{e}=$ Holli; $\mathrm{e}=$ Waama; $\mathrm{f}=$ Zerma); income $(\mathrm{a}=<50$ USD; $\mathrm{b}=50-170$ USD; $\mathrm{c}=170-330$ USD; $\mathrm{d}=>$ 330 USD; 1 USD = 590 F CFA on average, July 2016); land tenure $(a=$ no access; $b=$ purchase; $c=$ lease; $d=$ loan; $e=$ gift; $\mathrm{f}=$ heritage); education $(\mathrm{a}=$ illiterate; $\mathrm{b}=$ primary school; $\mathrm{c}=$ secondary school; $\mathrm{d}=$ university; $\mathrm{e}=$ literate (local language).

$54.0 \%$ of our Zerma informants harvested the plant in the wild and only $20.0 \%$ cultivated it in home gardens (MI, $5.0 \pm 2.7$ ). Land tenure had a significant influence on the MI $\left(D^{2}=17.6 \%, p<0.05\right)$ with the highest average value observed for lease $(11.3 \pm 4.8)$ mainly adopted by Ewe (61.6\%) respondents. Other land tenure regimes including purchase $(7.0 \pm 4.9)$, inheritance $(6.6 \pm 4.1)$, loan $(6.1 \pm 3.5)$, and gift $(4.6 \pm 3.2)$ were associated with lower MI scores. People with no land had the lowest MI $(4.6 \pm 3.0)$.

A significant variation was noticed in the perceived availability of the species across sociolinguistic groups (Kruskal-Wallis $\chi^{2}=194.3, \mathrm{df}=$ $6, p<0.001)$. While in Fon, Adja, Ewe, Gourmantche, and Waama communities, $G$. gynandra was regarded as a common species, the Holli and Zerma noticed that it was becoming rare in their region. The reasons cited to explain this rarity included (1) increasing urbanization, intensive crop production, and use of herbicides, which reduced the natural habitat of the species $(34.0 \%$ of respondents); (2) lack of knowledge about the reproductive biology $(33.0 \%)$; (3) erosion of knowledge (10.0\%); (4) low economic value $(8.5 \%)$; (5) low germination ability of the seeds (8.0\%); and (6) grazing by goats, pigs, and other animals (7.0\%). No selection of phenotypes was reported for the species.

The principal component analysis revealed that the variables related to the use of the species, the economic importance, and the management intensity were correlated with the first principal component $33.2 \%$ of variation explained) while the number of reported uses and the medicinal value of the species were correlated with the second principal component $(12.9 \%$ of variation explained) (Table 4). The frequency of uses and the last day of consumption were also significantly correlated with the third principal component, which explained $10.0 \%$ of the variation. 


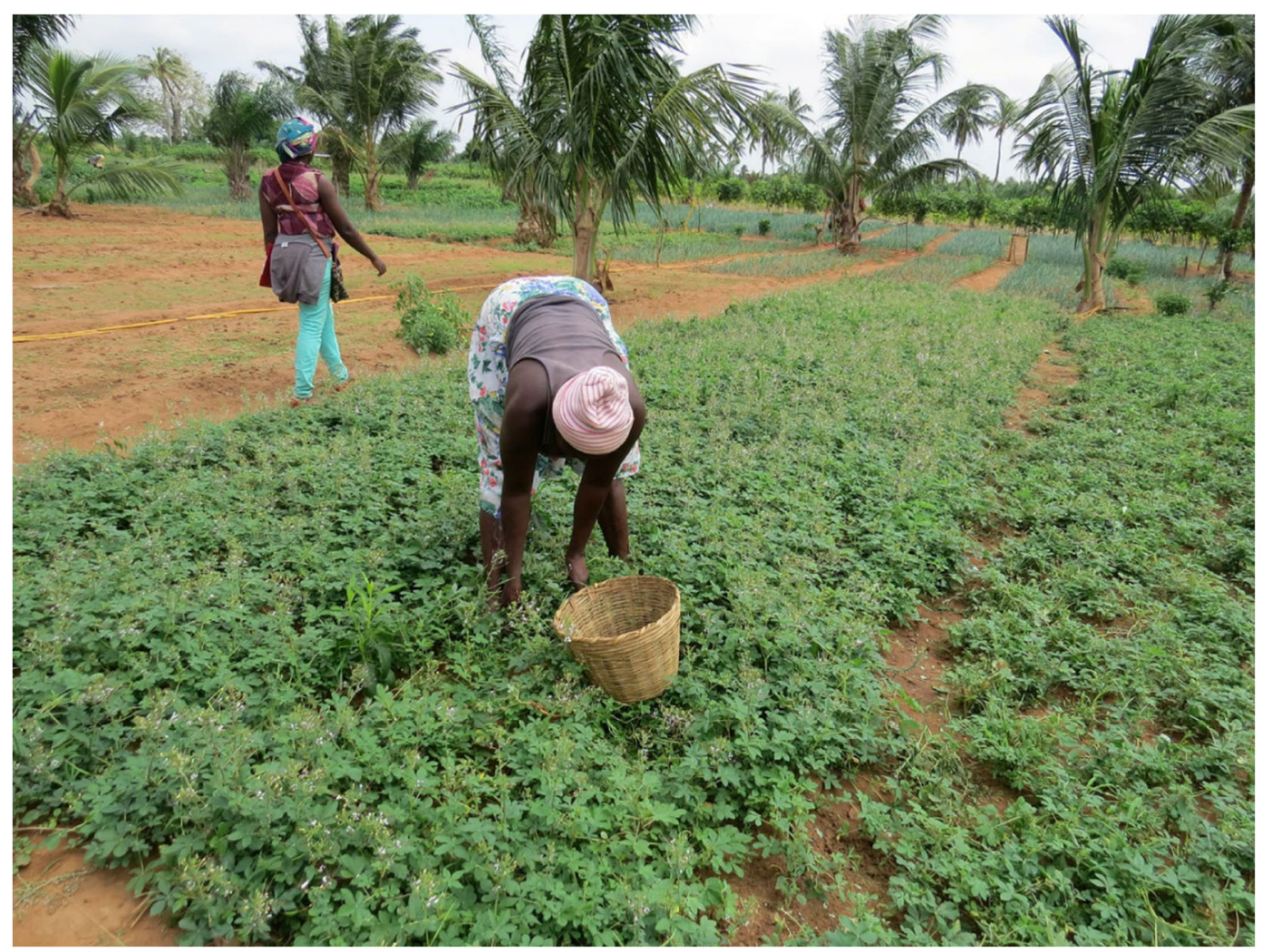

Fig. 4. Ewe woman harvesting spider plant leaves (Gynandropsis gynandra) in a market garden in Vogan County (Togo).

The projection of the respondents on dimensions 1,2 , and 3 (Fig. 5) supported the differences in knowledge, uses, and management of $G$. gynandra among socio-linguistic groups. The species had both high cultural and economic importance for the Adja and Ewe, which presented positive coordinates on the first dimension. The difference between both groups lies in the fact that the Adja also had a strong knowledge on the uses of the species (positive coordinates on dimension 2), while for the Ewe the species was mostly a vegetable. For all other groups, the species was both culturally and economically less important, apart from the Zerma, who showed a significant knowledge on the vegetable that they brought with them during their migration from Niger to Benin.

\section{Willingness to Improve CurRent Management Practices}

A significant and positive correlation was found between current and projected management regimes of $G$. gynandra $(\tau=0.52, p<0.001)$. Among the Adja, who cultivated the species in home gardens, $73 \%$ were willing to shift from rain-fed cultivation to intensive year-round cultivation. The Ewe would not significantly change their practices over time as they already intensively cultivated the species. In all the other socio-linguistic groups, rain-fed cultivation was considered as an interesting option for the future. The variation in management forms across socio-linguistic groups is depicted in Fig. 6.

The generalized estimating equation computed on the management forms used as repeated measures revealed a significant variation across sociolinguistic groups and across time as well as for the [time $\times$ socio-linguistic groups] interaction (Table 5 and Fig. 7).

The significant negative regression coefficient $(Z$ value $=-8.1, p<0.001)$ for the projected management practices suggested that the level of these practices would overall increase compared with the current management practices. The Adja 
TABLE 4. SCORES OF 14 VARIABLES RELATED TO CULTURAL IMPORTANCE, MANAGEMENT INTENSITY, AND ECONOMIC IMPORTANCE ON THREE FIRST PRINCIPAL COMPONENTS FOR USE OF GYNANDROPSIS GYNANDRA. SIGNIFICANT SCORES ARE IN ITALICS.

\begin{tabular}{lrrr}
\hline \hline & Dim1 & Dim2 & Dim3 \\
\hline Cultural importance indicators & & & -0.17 \\
Commercialization possibilities & 0.85 & -0.02 & -0.11 \\
Harvest type & 0.68 & 0.04 & 0.64 \\
Frequency of uses & 0.61 & 0.01 & 0.58 \\
Last day of consumption & 0.61 & 0.03 & 0.20 \\
Perceived availability & 0.60 & -0.18 & -0.36 \\
Plant parts used & 0.37 & 0.03 & 0.28 \\
Taste appreciation & 0.37 & 0.23 & 0.09 \\
Source of knowledge & 0.20 & 0.09 & -0.07 \\
Medicinal value & -0.01 & 0.90 & -0.06 \\
Number of reported uses & -0.01 & 0.93 & 0.44 \\
Food preparation & -0.18 & 0.18 & -0.24 \\
Management index & 0.85 & 0.05 & -0.27 \\
Economic value of leaves & 0.83 & -0.04 & 0.21 \\
Economic value of seeds & 0.78 & 0.01 & 10.04 \\
\% of variance explained & 33.16 & 12.96 & 56.16 \\
Cumulative \% of variance & 33.16 & 46.12 & \\
\hline
\end{tabular}

were used a reference for comparison with other socio-linguistic groups. The interaction between time and socio-linguistic groups suggests that the Ewe $(Z$ value $=8.1, p<0.001)$ would show significantly less change in management practices over time than the Adja. The negative interaction regression coefficients for the Fon, Gourmantche, and Holli suggested significantly higher rate of change in these groups compared to the Adja respondents. The non-significant interaction for the Zerma $(Z$ value $=0.6, p=0.537)$ and $\mathrm{Waama}(Z$ value $=-1.5$, $p=0.136)$ indicated that the management practices in these groups would not significantly change in the future compared to the Adja. However, the model suggested a higher change rate for the Waama than the Adja and a lower change rate for the Zerma than the Adja.

\section{Discussion}

\section{FACTORS INFLUENCING THE USE AND MANAGEMENT OF $G$. GYNANDRA}

We hypothesized that the variation in use and management of the species would be influenced by ethnicity, cultural and economic importance as well as the presence of market-oriented vegetable production. Our results indeed demonstrated strong ethnicity-driven patterns of knowledge, use, and valuation of spider plant. Ethnicity was also raised as an important factor in previous studies investigating variation in indigenous plant species knowledge (Ekué et al. 2010; Kidane et al. 2015). We observed that the cultural and economic importance varied across socio-linguistic groups and could be also explained by ethnicity.

The economic importance of the species was high among Adja and Ewe socio-linguistic groups. Both socio-linguistic groups are closely related and sometimes considered as the same ethnic community (Landoh et al. 2016) which may explain these similarities. While in the Ewe community, the species was only found among market gardeners who cultivate a wide diversity of vegetables, in the case of the Adja, the species was cultivated in rain-fed home gardens in pure stands and sold on local markets. We can therefore speculate that even in the absence of market-oriented vegetable production, local communities would domesticate the vegetable as soon as it becomes a popular and valued species. The differences noticed between both socio-linguistic groups in terms of cultural importance of the species suggested that urbanization could have resulted in less attention for the medicinal and cultural value of the species. Urbanization may jeopardize, increase, or have no effect on traditional knowledge transmission and conservation (Gaoue et al. 2017; Júnior et al. 2016). In our case, further comparison of 


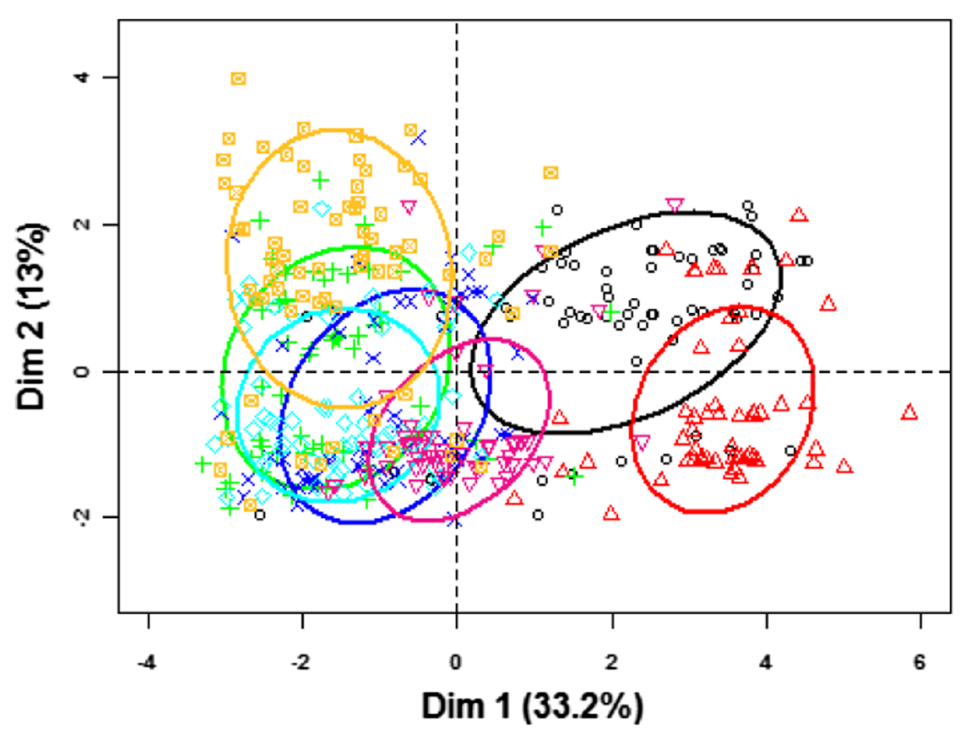

a

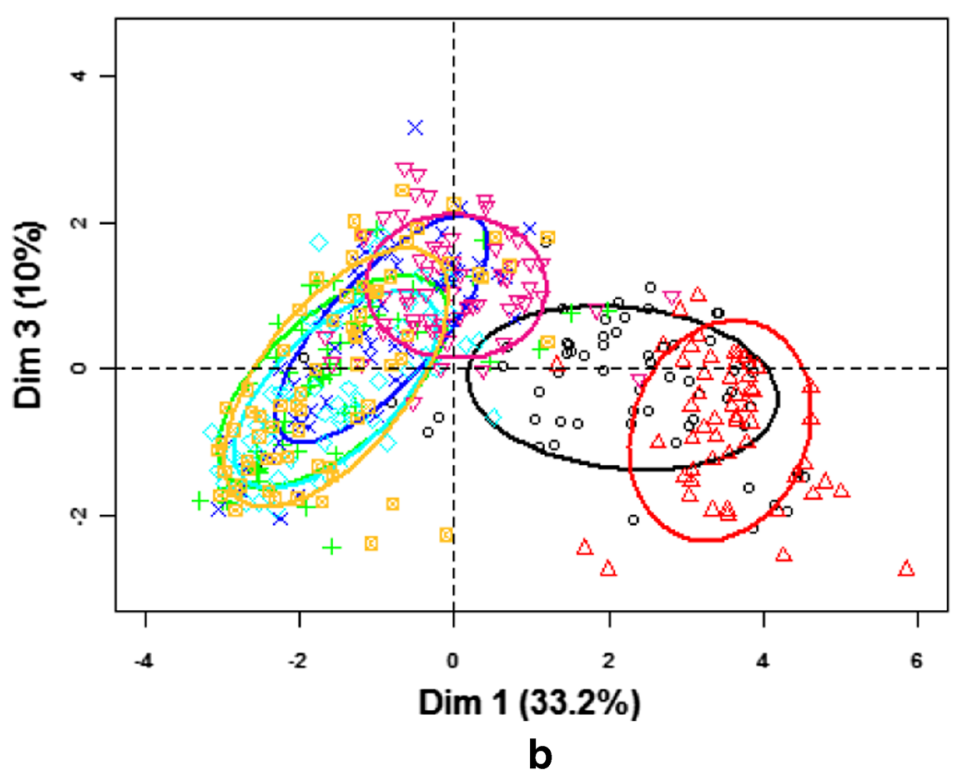

Socio-linguistic groups

- Adja

$\triangle$ Ewe

+ Fon

$\times$ Gourmantche Holli

7 Waama

Zerma

Fig. 5. PCA scores plot of 428 respondents from the different socio-linguistic groups based on knowledge and use and economic importance of Gynandropsis gynandra. (A) Projection on principal components 1 and 2. (B) Projection on principal components 1 and 3 .

traditional plant knowledge among urban and rural Ewe farmers would be required to test how urbanization affected their knowledge of the species.

Even though spider plant was perceived as abundant among the Fon, Gourmantche, and Waama groups-with strong awareness of usefulness - these communities did not consider the species as economically important and would only harvest it when needed for consumption or medicinal uses. The differences observed between knowledge and use among the different communities could be explained by discrepancies between 
Status

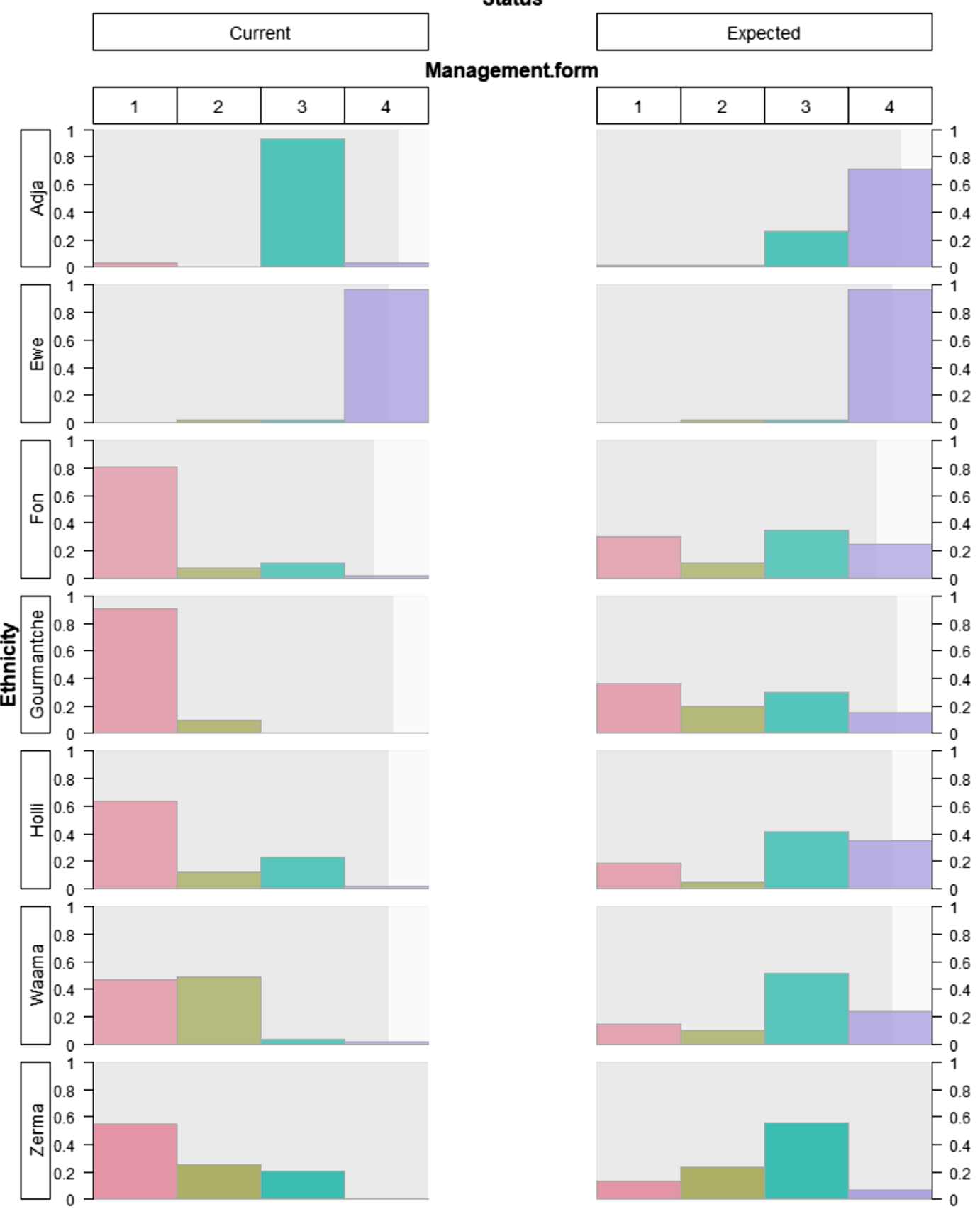

Fig. 6. Frequencies for current and expected management forms in each socio-linguistic group for use of Gynandropsis gynandra. Management forms: (1) wild collection with no particular selection; (2) tolerance, protection, or promotion of plants around houses; (3) rain-fed cultivation in home gardens; and (4) intensive irrigated cultivation all year round.

their ethnobotanical knowledge and their practical uses of the species (Godoy et al. 2009; Reyes-García et al. 2006). Albuquerque (2006) distinguished the notions of "mass knowledge" and "stock 
TABLE 5. ASSOCIATION BETWEEN CURRENT AND FUTURE MANAGEMENT SCHEMES ACROSS SOCIO-LINGUISTIC GROUPS.

\begin{tabular}{lcccccc}
\hline \hline & Estimates & Standard error & Odd ratios & $95 \%$ CI & $Z$ value & $p>|Z|$ \\
\hline$\beta 1$ & -2.17 & 0.16 & 0.11 & $0.08-0.15$ & -13.85 & $<2 \mathrm{e}-16^{* * *}$ \\
$\beta 2$ & -1.20 & 0.12 & 0.30 & $0.24-0.38$ & -9.98 & $<2 \mathrm{e}-16^{* * *}$ \\
$\beta 3$ & 1.19 & 0.11 & 3.29 & $2.66-4.06$ & 11.08 & $<2 \mathrm{e}-16^{* * *}$ \\
Current (reference) & & & & & & \\
Future & -1.87 & 0.23 & 0.15 & $0.10-0.24$ & -8.11 & $<2 \mathrm{e}-16^{* * *}$ \\
Adja (reference) & & & & & & \\
$\quad$ Ewe & -4.60 & 0.74 & 0.01 & $0.01-0.04$ & -6.23 & $<2 \mathrm{e}-16^{* * *}$ \\
Fon & 3.73 & 0.41 & 41.53 & $18.46-93.44$ & 9.01 & $<2 \mathrm{e}-16^{* * *}$ \\
$\quad$ Gourmantche & 4.65 & 0.52 & 104.99 & $37.52-293.78$ & 8.86 & $<2 \mathrm{e}-16^{* * *}$ \\
$\quad$ Holli & 2.65 & 0.30 & 14.18 & $7.85-25.60$ & 8.79 & $<2 \mathrm{e}-16^{* * *}$ \\
Waama & 2.44 & 0.23 & 11.49 & $7.33-18.03$ & 10.63 & $<2 \mathrm{e}-16^{* * *}$ \\
$\quad$ Zerma & 2.40 & 0.26 & 10.97 & $6.63-18.15$ & 9.33 & $<2 \mathrm{e}-16^{* * *}$ \\
Future: Adja (reference) & & & & & & \\
$\quad$ Future: Ewe & 1.87 & 0.23 & 6.51 & $4.14-10.23$ & 8.11 & $<2 \mathrm{e}-16^{* * *}$ \\
$\quad$ Future: Fon & -1.18 & 0.46 & 0.31 & $0.13-0.76$ & -2.55 & $0.013^{*}$ \\
$\quad$ Future: Gourmantche & -1.44 & 0.62 & 0.24 & $0.07-0.79$ & -2.33 & $0.019^{*}$ \\
$\quad$ Future: Holli & -1.05 & 0.39 & 0.35 & $0.16-0.75$ & -2.69 & $0.007^{* *}$ \\
Future: Waama & -0.54 & 0.36 & 0.58 & $0.29-1.18$ & -1.49 & $0.136^{\text {ns }}$ \\
Future: Zerma & 0.20 & 0.32 & 1.22 & $0.65-2.28$ & 0.62 & $0.537^{\text {ns }}$ \\
\hline
\end{tabular}

$C I$ confidence interval, $n s$ non-significant

${ }^{* * *} p<0.001 ;{ }^{* *} p<0.01 ;{ }^{*} p<0.05$

knowledge" which refer respectively to the total number of useful plants known by a community and the species actually used by them. In other words, some communities have a good knowledge of the species but would only use it as a last resort and prefer using other species with similar functions (e.g., food, medicine). This situation might change if there is an increasing market demand for the species. Other communities have a high preference for the species which, in the case of the Ewe and Adja, led to its cultivation and commercialization probably due to an increasing demand on the market. As previously reported by N'Danikou et al. (2011), the market importance of wild edible plants is also a main incentive for species' use and conservation. For example, our Zerma respondents, who originate from Niger, where the species is used and cultivated, cited the highest number of uses compared with any other socio-linguistic group. However, because of the low popularity and the lack of marketing opportunities for spider plant in Northern Benin, they used the species less frequently than the others and were less interested in its cultivation. Similar trends were observed for Artemisia absinthium, a plant species cultivated in Haiti for food, medicinal, and spiritual uses and with a high economic value. The species lost popularity over time among migrant Haitians in Cuba and its cultivation in home gardens declined substantially. Moreover, the species which was the main ingredient of the Tifey, a local beverage used for multiple purposes, was progressively replaced by other species more abundant in the host country (Volpato et al. 2009).

In the case of the Holli, the species was overall considered as rare and this community subsequently also had a low number of reported uses as well as frequency of uses and overall cultural importance. The link between species availability, knowledge, and actual use is therefore not straightforward but rather context-specific. In our case, the availability of the species was evaluated by the respondents based on how they perceive the balance between their demand and the abundance of the species in their community. To better account for the complexity of the concept of species availability, Gaoue et al. (2017) suggested a multi-dimensional index incorporating ecological, socio-cultural, economic, and political aspects and drivers of availability.

Patterns of plant uses and management often arise from complementarity between socio-cultural 


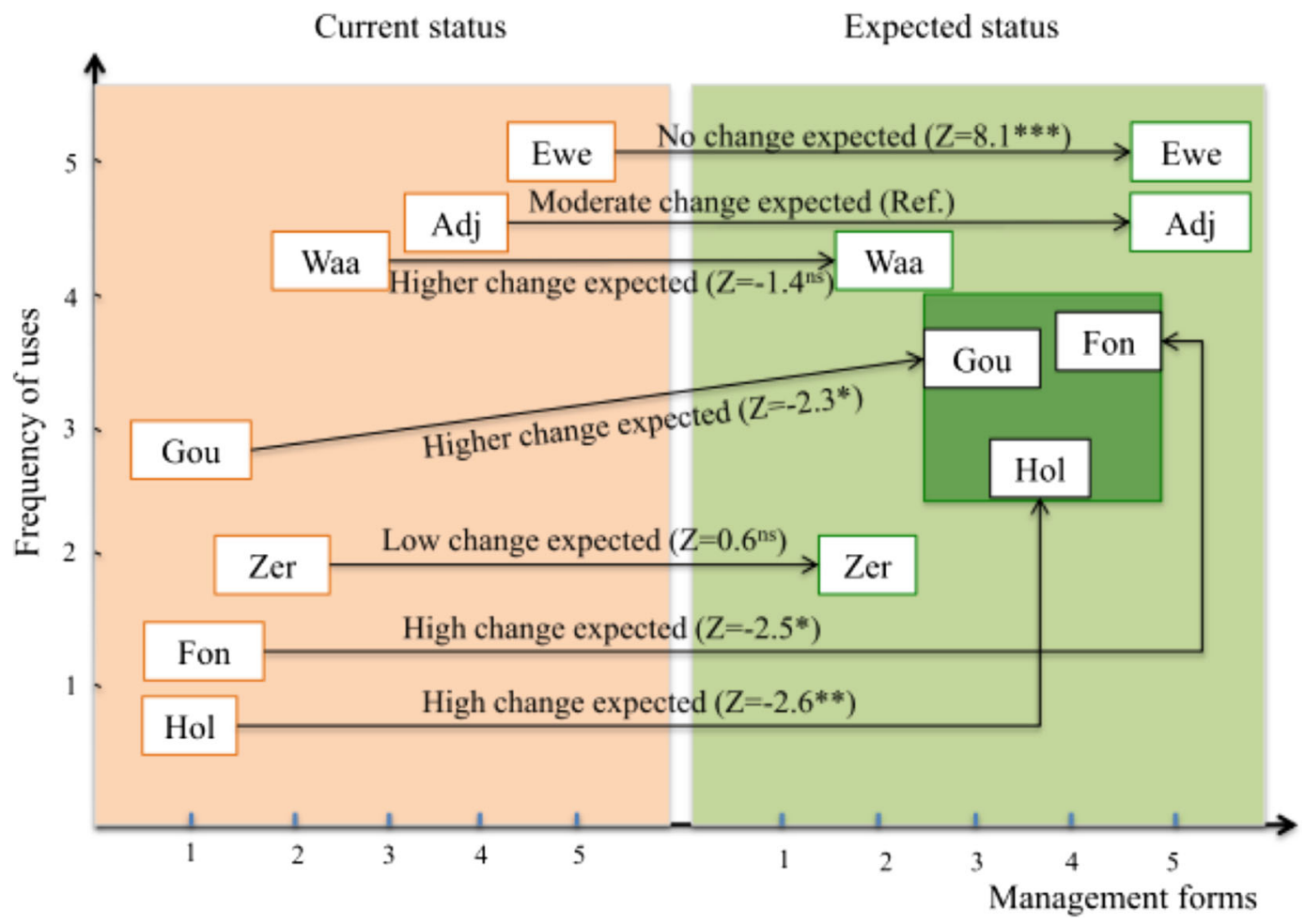

Fig. 7. Current and expected future management intensity $(\tau=0.52, p<0.001)$ of $G$. gynandra by socio-linguistic groups as main drivers $\left(D^{2}=65.9 \%\right)$ in Benin and Togo. Ewe: Ewe community, Adj: Adja community, Waa: Waama community, Gou: Gourmantche community, Zer: Zerma community, Fon: Fon community, Hol: Holly community. The greener area is where the leverage activities should be intensified.

attributes and biogeographical factors. Communities sharing the same environment but with different cultural backgrounds may have convergent plant uses (Segnon and Achigan-Dako 2014; van Andel et al. 2015). We observed patterns of convergence in use and management between communities sharing a same cultural background and living in the same geographical area. For the Gourmantche and the Waama who belong to the Gur language family (CENALA 2003) and live in the Sudanian semiarid region, the species has a lower cultural importance and is less intensively managed compared with the Adja and Ewe who belong to the Kwa language family and live in the Guineo-Congolian humid region. Although our data supports the hypothesis that management and uses are shaped by ethnicity and geographical proximity, an exception is that among the Fon who also belong to the Kwa language family and are geographically close to the Adja and Ewe (CENALA 2003), the species is much less popular as a vegetable, but more as a medicinal plant, and thus managed less intensively.
The name of the species is also the same among the Ewe and Adja, suggesting strong cultural affinities, but different for the Fon who are more culturally distant from those socio-linguistic groups. Wartena (2006) explained that the Fon and the Adja shared their climate, geological conditions, trade opportunities, and cultural origins of their populations. However, divergences between the two sociolinguistic groups was traced back to pre-colonial times, first in trade and culture contacts with neighbors and then in the socio-economic and cultural practices of the slave raiding and trading Fon on the one hand and the agrarian Adja hiding from slave raiders on the other. The author also described in details the current differences in the traditional beliefs, agricultural practices, and food preferences between these communities.

A commonality between all the surveyed sociolinguistic groups is the knowledge about the medicinal uses of the species. The use of spider plant to cure malaria and anemia respectively by the Fon and the Mahi were previously reported in southern 
Benin (Allabi et al. 2011; Yetein et al. 2013). Medicinal uses of the species were also reported in other parts of the world including India (Bala et al. 2010; Shanmugam et al. 2012), Uganda (Oryema et al. 2010), and Kenya (Jeruto et al. 2008). The use of the species as a medicinal plant across several sociolinguistic groups in Benin suggests its proven efficacy. Its occurrence in anthropogenic areas as an herb that grows at the onset of the rainy season makes it easily available when needed. Such characteristics are in accordance with the "availability" and the "ecological apparency" hypotheses commonly used to explain the predominance of weeds in medicinal flora. The availability hypothesis states that accessible or locally abundant plants are more likely to be used as medicinal plants. The ecological apparency hypothesis speculates that species with short lifespan (non-apparent species) develop "inexpensive" qualitative defense compounds against herbivores (secondary metabolites) (Albuquerque 2006; Gaoue et al. 2017). Those compounds also have beneficial health-promoting properties. Spider plant leaves are indeed rich in glucosinolates and flavonoids which are involved in response against environmental stresses (Omondi et al. 2017), but also have pharmacological properties (Bala et al. 2014; Moyo et al. 2013).

During our sampling, we noticed that the management of the species was gender-specific. Most of our respondents were female. However, in the Ewe community, with a high economic orientation to the cultivation of spider plant, producers were predominantly males. In the other socio-linguistic groups, women managed the species for household consumption and in rain-fed cultivation in home gardens and sold it occasionally on local markets. In Benin, it was reported that women are typically involved in the domestication of leafy vegetables and medicinal plants while fruit domestication is controlled by men (Vodouhè and Dansi 2012). The predominance of males in commercial production is explained by the fact that commercial vegetable production requires important financial resources for land lease, irrigation, and purchase of various inputs. For male Ewe respondents, vegetable production was a full-time job. Only few women were encountered during our survey in Togo and they were much more involved as hired laborers and vegetable traders. Several studies conducted in urban areas of West Africa reported the male dominance in vegetable production, while women lead vegetable marketing (Drechsel et al. 2013; Gockowski et al. 2003). However, peri-urban and rural vegetable production is often dominated by women who mainly grow African leafy vegetables as these require lower amounts of external inputs and financial resources than non-indigenous vegetables (Dinssa et al. 2016). Adja women who lived in periurban and rural areas were considered by their male counterparts as more knowledgeable about the uses and growth of the species. The same behavior was noticed for all the other socio-linguistic groups in Benin, where male farmers considered that "only women manage the species for culinary purposes". These trends suggest an increasing interest from men when the species becomes economically important. Research for development initiatives aiming at promoting African leafy vegetables should therefore put an emphasis on ensuring women's access to key agricultural production factors including land, labor, and financial asset.

In the Adja community, we observed a strong willingness to shift towards intensive year-round cultivation of the species, which would require higher investment of resources from women. The commercial cultivation of the species by the Ewe in Togo is a unique opportunity to identify and address the main constraints related to agronomy of the species. Rain-fed cultivation of the species in home gardens was considered as an attractive option among the Fon, Holli, Gourmantche, and Waama. These groups have access to land, but external factors including farmers' training on adequate cultivation practices and leverage activities should also be taken into account to support their efforts. Strategies for integration of wild edible plants in the market should take into account the issues of production, storage and processing, organization of wild edible plants supply chains, and negative perceptions of their consumption, often associated with poverty and low social status (Leal et al. 2018). The promotion of Moringa oleifera in several African countries is an example of successful diffusion of innovation consistent with existing social and cultural practices (Thurber and Fahey 2009). Intensive cultivation of the species year-round in the surveyed communities would require interventions to create public awareness about the nutritional and health benefits of the species and other wild leafy vegetables. Potential consumers including women, youths, and elite class citizens with high income in urban and peri-urban areas should be targeted in order to increase the demand in the vegetable. Participatory breeding efforts to provide farmers with high-yielding and nutritious varieties as well as investigation on optimal seed storage and 
conservation are also necessary to sustain the species cultivation.

\section{Limitations of OUR STUdy}

The purposive sampling method in ethnobotany has been often criticized as the results cannot be generalized to the whole community (Tongco 2007). In our study, however, this method was the most convenient as we needed to identify people who knew the species and were willing to participate in the study. Another unavoidable bias in our study was the gender skewness of our sample. In most households we visited, men directed us to women who were in charge of collecting or cultivating vegetables for cooking and commercialization. Because of the subjective character of some of the variables collected, repeated interviews in time would allow better triangulation of our data. However, this approach would be time-consuming and costly.

The cultural significance index and the management index were both adapted to the context of our study. The choice of the cultural significance index was guided by the need to analyze the perceptions of the respondents. Other cultural importance indices developed in literature were used to compare species and were restricted to the comparison between the number of respondents who mentioned some uses of a species in defined use-categories (Tardío and Pardo-de-Santayana 2008). However, we do not pretend to have exhaustively taken into account all the aspects to consider when evaluating the cultural significance or the management intensity of a plant species. For example, determining the relative cultural importance of spider plant compared with other leafy vegetables in the surveyed communities would have allowed to better assess the species availability, use, and management. Such information coupled with a discrete choice experiment (Espinosa-Goded et al. 2010; Schulz et al. 2014) and an analysis of market opportunities could also improve our evaluation of respondents' willingness to integrate the species in their home gardens.

\section{Conclusion}

Our study provides insight in the knowledge, use, and management of Gynandropsis gynandra in seven socio-linguistic groups in Benin and Togo. Communities had a good knowledge of the nutritional and medicinal value of the species. However, cultural importance of the species and management practices across these communities were diverse and strongly influenced by ethnicity and gender and to a lesser extent by age, education, and access to land. We observed overall a convergence of knowledge and management practices between communities with similar socio-cultural and ecological contexts. Migration and available market opportunities also significantly influenced the management practices adopted by our respondents. In areas where $G$. gynandra is still harvested from the wild, promotion of the species among consumers and farmers' training, especially women, are expected to trigger the species' cultivation. Efficient selection of neglected plant species to promote in a given region for successful commercial cultivation should take into account not only their nutritional value and pharmacological properties but also communities' willingness to intensify management of these species with a particular emphasis on potential sociocultural and economic constraints which could arise during such an intensification process.

\section{Acknowledgements}

We would like to thank Chaldia Agossou, Jelila Blalogoe, and Xavier Matro for their assistance during data collection and Alcade Segnon for his insightful comments. We are grateful to the respondents for kindly sharing their knowledge with us. We also appreciated the support of the local authorities in all the surveyed areas.

\section{Funding Information}

This study was financially supported by the WOTRO Applied Research Fund (Project Number W.08.270.350) and the Schlumberger Foundation Faculty for the Future.

Open Access This article is distributed under the terms of the Creative Commons Attribution 4.0 International License (ht t p:// creativecommons.org/licenses/by/4.0/), which permits unrestricted use, distribution, and reproduction in any medium, provided you give appropriate credit to the original author(s) and the source, provide a link to the Creative Commons license, and indicate if changes were made.

\section{Literature Cited}

Abasse, T. A., A. Gouzayé, L. Woltering, and D. Pasternak. 2007. The role of indigenous leafy vegetables on daily diet and rural and urban economy in Niger. Acta Horticulturae 752: 35-40. 
Achigan-Dako, E. G., M. W. Pasquini, F. Assogba Komlan, S. N'Danikou, H. Yédomonhan, A. Dansi, and B. Ambrose-Oji. 2010. Traditional vegetables in Benin. Cotonou: Institut National des Recherches Agricoles du Bénin, Imprimeries du CENAP

, S. N'Danikou, F. Assogba-Komlan, B. Ambrose-Oji, A. Ahanchede, and M. W. Pasquini. 2011. Diversity, geographical, and consumption patterns of traditional vegetables in sociolinguistic communities in Benin: Implications for domestication and utilization. Economic Botany 65(2): 129-145.

Akoègninou, A., W. J. Van der Burg, and L. J. G. Van der Maesen. 2006. Flore analytique du Bénin. Wageningen: Backhuys Publishers.

Albuquerque, U. P. 2006. Re-examining hypotheses concerning the use and knowledge of medicinal plants: A study in the Caatinga vegetation of NE Brazil. Journal of Ethnobiology and Ethnomedicine 2(1): 30. https://doi.org/10.1186/ 1746-4269-2-30

- L. V. F. Cruz da Cunha, R. F. P. de Lucena, R. R. N. Alves, M. A. Ramos, and N. L. Alencar. 2014. Methods and techniques used to collect ethnobiological data. In: Methods and techniques in ethnobiology and ethnoecology, eds. Albuquerque, U. P., L. V. F. Cruz da Cunha, R. F. P. de Lucena, and R. R. N. Alves, 1537. New York: Springer.

Allabi, A. C., K. Busia, V. Ekanmian, and F. Bakiono. 2011. The use of medicinal plants in self-care in the Agonlin region of Benin. Journal of Ethnopharmacology 133(1): 234-243.

Arellanes, Y., A. Casas, A. Arellanes, E. Vega, J. Blancas, M. Vallejo, I. Torres, S. Rangel-Landa, A. I. Moreno, L. Solís, and E. Pérez-Negrón. 2013. Influence of traditional markets on plant management in the Tehuacán Valley. Journal of Ethnobiology and Ethnomedicine 9(1): 38. https://doi.org/10.1186/1746-4269-9-38

Arora, R. K. 2014. Diversity in underutilized plant species_-an Asia-Pacific perspective. New Delhi: Bioversity International.

Bala, A., B. Kar, P. K. Haldar, U. K. Mazumder, and S. Bera. 2010. Evaluation of anticancer activity of Cleome gynandra on Ehrlich's ascites carcinoma treated mice. Journal of Ethnopharmacology 129(1): 131-134.

- P. Chetia, N. Dolai, B. Khandelwal, and P. K. Haldar. 2014. Cat's whiskers flavonoid attenuated oxidative DNA damage and acute inflammation: Its importance in lymphocytes of patients with rheumatoid arthritis. Inflammopharmacology 22(1): 55-61.

Barbosa, A. M., J. A. Brown, A. Jimenez-Valverde, and R. Real. 2016. modEvA: Model evaluation and analysis. $\mathrm{R}$ package version 1.3.2. https:// CRAN.R-project.org/package $=$ modEvA

Blancas, J., A. Casas, S. Rangel-Landa, A. MorenoCalles, I. Torres, E. Pérez-Negrón, L. Solís, A. Delgado-Lemus, F. Parra, Y. Arellanes, J. Caballero, L. Cortés, R. Lira, and P. Dávila. 2010. Plant management in the Tehuacán-Cuicatlán valley, Mexico. Economic Botany 64(4): 287302.

, D. Pérez-Salicrup, J. Caballero, and E. Vega. 2013. Ecological and socio-cultural factors influencing plant management in Náhuatl communities of the Tehuacán Valley, Mexico. Journal of Ethnobiology and Ethnomedicine 9(1): 39. https://doi.org/10.1186/ 1746-4269-9-39

CENALA. 2003. Atlas et études sociolinguistiques du Bénin. Cotonou: Agence Intergouvernementale de la Francophonie.

Ceuterick, M., I. Vandebroek, B. Torry, and A. Pieroni. 2008. Cross-cultural adaptation in urban ethnobotany: The Colombian folk pharmacopoeia in London. Journal of Ethnopharmacology 120(3): 342-359.

Cleome Consortium. 2016. Utilizing the genome of Cleome gynandra for the development of improved cultivars for West and East African markets-annual progress report 2015. Cotonou: Cleome Consortium.

Cruz, M. P., N. Peroni, and U. P. Albuquerque. 2013. Knowledge, use and management of native wild edible plants from a seasonal dry forest (NE, Brazil). Journal of Ethnobiology and Ethnomedicine 9: 1. https://doi.org/10.1186/17464269-9-79

de Lucena, R. F. P., E. de Lima Araújo, and U. P. de Albuquerque. 2007. Does the local availability of woody Caatinga plants (Northeastern Brazil) explain their use value? Economic Botany 61(4): 347-361.

Dinssa, F. F., P. Hanson, T. Dubois, A. Tenkouano, T. Stoilova, J. Hughes, and J. D. H. Keating. 2016. AVRDC-The World Vegetable Center's women-oriented improvement and development strategy for traditional African vegetables in sub-Saharan Africa. European Journal of Horticultural Science 81(2): 91-105.

Dovie, D. B. K., C. M. Shackleton, and E. T. F. Witkowski. 2007. Conceptualizing the human 
use of wild edible herbs for conservation in South African communal areas. Journal of Environmental Management 84(2): 146-156.

Drechsel, P., L. Hope, and O. O. Cofie. 2013. Gender mainstreaming: who wins? Gender and irrigated urban vegetable production in West Africa. wH2O: Journal of Gender and Water 2(1): 15-17.

Ekué, M. R. M., B. Sinsin, O. Eyog-Matig, and R. Finkeldey. 2010. Uses, traditional management, perception of variation and preferences in ackee (Blighia sapida K.D. Koenig) fruit traits in Benin: Implications for domestication and conservation. Journal of Ethnobiology and Ethnomedicine 6: 12. https://doi.org/10.1186/17464269-6-12

Espinosa-Goded, M., J. Barreiro-Hurlé, and E. Ruto. 2010. What do farmers want from agrienvironmental scheme design? A choice experiment approach Journal of Agricultural Economics 61(2): 259-273.

Floress, K., A. Reimer, A. Thompson, M. Burbach, C. Knutson, L. Prokopy, M. Ribaudo, and J. Ulrich-Schad. 2018. Measuring farmer conservation behaviors: Challenges and best practices. Land Use Policy 70: 414-418.

Gaoue, O. G., M. A. Coe, M. Bond, G. Hart, B. C. Seyler, and H. McMillen. 2017. Theories and major hypotheses in ethnobotany. Economic Botany 71(3): 269-287.

Georgian, E., and E. Emshwiller. 2013. Shared and separate knowledge among eight cultural groups based on ethnobotanical uses of Rhododendron (Ericaceae) in Yunnan Province, China. Economic Botany 67(3): 191-202.

Ghimire, S. K., D. McKey, and Y. AumeeruddyThomas. 2004 . Heterogeneity in ethnoecological knowledge and management of medicinal plants in the Himalayas of Nepal: Implications for conservation. Ecology and Society 9(3): 6. http://www.ecologyandsociety.org/ vol9/iss3/art6/

Ghorbani, A., G. Langenberger, and J. Sauerborn. 2012. A comparison of the wild food plant use knowledge of ethnic minorities in Naban River Watershed National Nature Reserve, Yunnan, SW China. Journal of Ethnobiology and Ethnomedicine 8: 17. https://doi.org/10.1186/17464269-8-17

Gockowski, J., J. Mbazo'o, G. Mbah, and T. Fouda Moulende. 2003. African traditional leafy vegetables and the urban and peri-urban poor. Food Policy 28(3): 221-235.
Godoy, R., V. Reyes-Garcia, J. Broesch, I. C. Fitzpatrick, P. Giovannini, M. R. M. Rodriguez, T. Huanca, W. R. Leonard, T. W. McDade, and S. Tanner. 2009. Longterm (secular) change of ethnobotanical knowledge of useful plants: Separating cohort and age effects. Journal of Anthropological Research 65(1): 51-67.

González-Insuasti, M. S., and J. Caballero. 2007. Managing plant resources: How intensive can it be? Human Ecology 35(3): 303-314.

, C. Martorell, and J. Caballero. 2008. Factors that influence the intensity of nonagricultural management of plant resources. Agroforestry Systems 74(1): 1-15.

González-Insuasti, M. S., A. Casas, I. MéndezRamírez, C. Martorell, and J. Caballero. 2011. Intra-cultural differences in the importance of plant resources and their impact on management intensification in the Tehuacán Valley, Mexico. Human Ecology 39(2): 191-202.

Hart, G., O. G. Gaoue, L. de la Torre, H. Navarrete, P. Muriel, M. J. Macía, H. Balslev, S. León-Yánez, P. Jørgensen, and D. C. Duffy. 2017. Availability, diversification and versatility explain human selection of introduced plants in Ecuadorian traditional medicine. PLoS ONE 12(9). https://doi.org/10. 1371/journal.pone.0184369

Hounkpati, B. C. C. 1991. A comparative phonology of Gbe. Berlin: Foris Publications.

Jeruto, P., C. Lukhoba, G. Ouma, D. Otieno, and C. Mutai. 2008. An ethnobotanical study of medicinal plants used by the Nandi people in Kenya. Journal of Ethnopharmacology 116(2): 370-376.

Júnior, W. S. F., F. R. Santoro, I. Vandebroek, and U. P. Albuquerque. 2016. Urbanization, modernization, and nature knowledge. In: Introduction to ethnobiology, eds. Albuquerque, U. P., and R. R. Nóbrega Alves, 251-256. Switzerland: Springer International Publishing.

Kidane, B., L. J. G. van der Maesen, Z. Asfaw, M. S. M. Sosef, and T. van Andel. 2015. Wild and semi-wild leafy vegetables used by the Maale and Ari ethnic communities in southern Ethiopia. Genetic Resources and Crop Evolution 62(2): 221-234.

Kujawska, M., and M. Pardo-de-Santayana. 2015. Management of medicinally useful plants by European migrants in South America. Journal of Ethnopharmacology 172: 347-355.

Landoh, D. E., F. Ouro-Kavalah, I. Yaya, A.-L. Kahn, P. Wasswa, A. Lacle, D. I. Nassoury, S. 
N. Gitta, and A. B. Soura. 2016. Predictors of incomplete immunization coverage among one to five years old children in Togo. BMC Public Health 16: 968. https://doi.org/10.1186/ s12889-016-3625-5

LaRochelle, S., and F. Berkes. 2003. Traditional ecological knowledge and practice for edible wild plants: Biodiversity use by the Rarámuri, in the Sirerra Tarahumara, Mexico. International Journal of Sustainable Development \& World Ecology 10(4): 361-375.

Leal, M. L., R. P. Alves, and N. Hanazaki. 2018. Knowledge, use, and disuse of unconventional food plants. Journal of Ethnobiology and Ethnomedicine 14: 6. https://doi.org/10.1186/ s13002-018-0209-8

Lozada, M., A. Ladio, and M. Weigandt. 2006. Cultural transmission of ethnobotanical knowledge in a rural community of northwestern Patagonia, Argentina. Economic Botany 60(4): 374-385.

Łuczaj, Ł., A. Pieroni, J. Tardío, M. Pardo-de-Santayana, R. Sóukand, I. Svanberg, and R. Kalle. 2012. Wild food plant use in 21 st century Europe: The disappearance of old traditions and the search for new cuisines involving wild edibles. Acta Societatis Botanicorum Poloniae 81(4): 359-370.

———, P. Köhler, E. Pirożnikow, M. Graniszewska, A. Pieroni, and T. Gervasi. 2013. Wild edible plants of Belarus: From Rostafiński's questionnaire of 1883 to the present. Journal of Ethnobiology and Ethnomedicine 9: 21. https://doi.org/10.1186/1746-42699-21

Mathez-Stiefel, S.-L., and I. Vandebroek. 2012. Distribution and transmission of medicinal plant knowledge in the Andean highlands: A case study from Peru and Bolivia. Evidence-Based Complementary and Alternative Medicine 2012: 18. https://doi.org/10.1155/2012/ 959285

Medeiros, P. M. d., G. T. Soldati, N. L. Alencar, I. Vandebroek, A. Pieroni, N. Hanazaki, and U. P. de Albuquerque. 2012. The use of medicinal plants by migrant people: Adaptation, maintenance, and replacement. Evidence-Based Complementary and Alternative Medicine 2012: 11. https://doi.org/10.1155/2012/807452

Menendez-Baceta, G., M. Pardo-de-Santayana, L. Aceituno-Mata, J. Tardío, and V. Reyes-García. 2017. Trends in wild food plants uses in Gorbeialdea (Basque Country). Appetite 112: 9-16.
Monteiro, J. M., U. P. d. Albuquerque, E. M. d. F. Lins-Neto, E. L. d. Araújo, and E. L. C. d. Amorim. 2006. Use patterns and knowledge of medicinal species among two rural communities in Brazil's semi-arid northeastern region. Journal of Ethnopharmacology 105(1): 173-186.

Moyo, M., S. O. Amoo, B. Ncube, A. R. Ndhlala, J. F. Finnie, and J. Van Staden. 2013. Phytochemical and antioxidant properties of unconventional leafy vegetables consumed in southern Africa. South African Journal of Botany 84: 6571.

Muhammad, A. 2016. The derivational processes in the Zarma numeral system. In: The numeral systems of Nigerian languages, eds. Ndimele, O., and E. S. L. Chan, 295-302. Port Harcourt: M\&J Orbit Communications.

N'Danikou, S., E. G. Achigan-Dako, D. A. Tchokponhoue, C. O. A. Agossou, C. A. Houdegbe, R. S. Vodouhe, and A. Ahanchede. 2015. Modelling socioeconomic determinants for cultivation and in-situ conservation of Vitex doniana Sweet (Black plum), a wild harvested economic plant in Benin. Journal of Ethnobiology and Ethnomedicine 11: 28. https://doi.org/ 10.1186/s13002-015-0017-3

— $—$ and J. Wong. 2011. Eliciting local values of wild edible plants in Southern Benin to identify priority species for conservation. Economic Botany 65(4): 381-395.

Nooraee, N., G. Molenberghs, and E. R. van den Heuvel. 2014. GEE for longitudinal ordinal data: Comparing R-geepack, R-multgee, Rrepolr, SAS-GENMOD, SPSS-GENLIN. Computational Statistics \& Data Analysis 77: 70-83.

Oluoch, M. O., G. N. Pichop, D. Silué, M. O. Abukutsa-Onyango, M. Diouf, and C. M. Shackleton. 2009. Production and harvesting systems for African indigenous vegetables. In: African indigenous vegetables in urban agriculture, eds. Shackleton, C., A. W. Drescher, and M. W. Pasquini, 145176. London: Earthscan.

Omondi, E. O., C. Engels, G. Nambafu, M. Schreiner, S. Neugart, M. Abukutsa-Onyango, and T. Winkelmann. 2017. Nutritional compound analysis and morphological characterization of spider plant (Cleome gynandra) - an African indigenous leafy vegetable. Food Research International 100: 284-295.

Ong, H. G., and Y.-D. Kim. 2017. The role of wild edible plants in household food security among 
transitioning hunter-gatherers: Evidence from the Philippines. Food Security 9(1): 11-24.

Onyango, C. M., C. N. Kunyanga, E. G. Ontita, R. D. Narla, and J. W. Kimenju. 2013. Production, utilisation and indigenous knowledge of spider plant in Kenya. African Crop Science Conference Proceedings 11: 925-930.

Oryema, C., R. B. Ziraba, N. Omagor, and A. Opio. 2010. Medicinal plants of Erute county, Lira District, Uganda with particular reference to their conservation. African Journal of Ecology 48: 285-298.

Parsons, N. R., M. L. Costa, J. Achten, and N. Stallard. 2009. Repeated measures proportional odds logistic regression analysis of ordinal score data in the statistical software package R. Computational Statistics \& Data Analysis 53(3): 632-641.

Pawera, L., Ł. Łuczaj, A. Pieroni, and Z. Polesny. 2017. Traditional plant knowledge in the White Carpathians: Ethnobotany of wild food plants and crop wild relatives in the Czech Republic. Human Ecology 45(5): 655-671.

Pieroni, A. 2001. Evaluation of the cultural significance of wild food botanicals traditionally consumed in Northwestern Tuscany, Italy. Journal of Ethnobiology 21(1): 89-104.

Pirker, H., R. Haselmair, E. Kuhn, C. Schunko, and C. R. Vogl. 2012. Transformation of traditional knowledge of medicinal plants: The case of Tyroleans (Austria) who migrated to Australia, Brazil and Peru. Journal of Ethnobiology and Ethnomedicine 8: 44. https://doi.org/10.1186/ 1746-4269-8-44

Quinlan, M. B., and R. J. Quinlan. 2007. Modernization and medicinal plant knowledge in a Caribbean horticultural village. Medical Anthropology Quarterly 21(2): 169-192.

Reyes-Garcia, V., V. Vadez, E. Byron, L. Apaza, W. R. Leonard, E. Perez, and D. Wilkie. 2005. Market economy and the loss of folk knowledge of plant uses: Estimates from the Tsimane' of the Bolivian Amazon. Current Anthropology 46(4): 651-656.

, T. Huanca, W. Leonard, and D.

Wilkie. 2005. Knowledge and consumption of wild plants: A comparative study in two Tsimane'villages in the Bolivian Amazon. Ethnobotany Research \& Applications 3: 201-208.

, Reyes-García, V., T. Huanca, V. Vadez, W. Leonard, and D. Wilkie. 2006. Cultural, practical, and economic value of wild plants: A quantitative study in the Bolivian Amazon. Economic Botany 60(1): 62-74.

- J. Broesch, L. Calvet-Mir, N. FuentesPeláez, T. W. McDade, S. Parsa, S. Tanner, T. Huanca, W. R. Leonard, and M. R. MartínezRodríguez. 2009. Cultural transmission of ethnobotanical knowledge and skills: An empirical analysis from an Amerindian society. Evolution and Human Behavior 30(4): 274-285.

Ripley, B. 2016. tree: Classification and regression trees. R package version 1.37. https://CRAN.Rproject.org/package $=$ tree

Romojaro, A., M. Á. Botella, C. Obón, and M. T. Pretel. 2013. Nutritional and antioxidant properties of wild edible plants and their use as potential ingredients in the modern diet. International Journal of Food Sciences and Nutrition 64(8): 944-952.

Sansanelli, S., M. Ferri, M. Salinitro, and A. Tassoni. 2017. Ethnobotanical survey of wild food plants traditionally collected and consumed in the Middle Agri Valley (Basilicata region, southern Italy). Journal of Ethnobiology and Ethnomedicine 13: 50. https://doi.org/10. 1186/s13002-017-0177-4

Schulp, C. J. E., W. Thuiller, and P. H. Verburg. 2014. Wild food in Europe: A synthesis of knowledge and data of terrestrial wild food as an ecosystem service. Ecological Economics 105: 292-305.

Schulz, N., G. Breustedt, and U. Latacz-Lohmann. 2014. Assessing farmers' willingness to accept "greening": Insights from a discrete choice experiment in Germany. Journal of Agricultural Economics 65(1): 26-48.

Segnon, A. C., and E. G. Achigan-Dako. 2014. Comparative analysis of diversity and utilization of edible plants in arid and semi-arid areas in Benin. Journal of Ethnobiology and Ethnomedicine 10: 80. https://doi.org/10.1186/1746-4269-10-80

Shanmugam, S., K. Rajendran, and K. Suresh. 2012. Traditional uses of medicinal plants among the rural people in Sivagangai district of Tamil Nadu, Southern India. Asian Pacific Journal of Tropical Biomedicine 2(1, Supplement): S429-S434.

Soares, D. T. N., J. C. Sfair, V. Reyes-García, and C. Baldauf. 2017. Plant knowledge and current uses of woody flora in three cultural groups of the Brazilian semiarid region: Does culture matter? Economic Botany 71(4): 314-329. 
Sundriyal, M., and R. Sundriyal. 2004. Wild edible plants of the Sikkim Himalaya: Marketing, value addition and implications for management. Economic Botany 58(2): 300-315.

Tardío, J., and M. Pardo-de-Santayana. 2008. Cultural importance indices: A comparative analysis based on the useful wild plants of Southern Cantabria (Northern Spain). Economic Botany 62(1): 24-39.

Thurber, M. D., and J. W. Fahey. 2009. Adoption of Moringa oleifera to combat under-nutrition viewed through the lens of the "diffusion of innovations" theory. Ecology of Food and Nutrition 48(3): 212-225.

Tongco, M. D. C. 2007. Purposive sampling as a tool for informant selection. Ethnobotany Research \& Applications 5: 147-158.

van Andel, T., and P. Westers. 2010. Why Surinamese migrants in the Netherlands continue to use medicinal herbs from their home country. Journal of Ethnopharmacology 127(3): 694-701.

S. Ruysschaert, K. Boven, and L. Daly. 2015. The use of Amerindian charm plants in the Guianas. Journal of Ethnobiology and Ethnomedicine 11: 66. https://doi.org/10.1186/ s13002-015-0048-9

van den Boog, T., T. van Andel, and J. Bulkan. 2017. Indigenous children's knowledge about non-timber forest products in Suriname. Economic Botany 71(4): 361-373.

Vandebroek, I., and M. J. Balick. 2012. Globalization and loss of plant knowledge: Challenging the paradigm. PLoS ONE 7(5). https://doi.org/ 10.1371/journal.pone. 0037643

Vodouhè, R., and A. Dansi. 2012. The "Bringing into Cultivation" phase of the plant domestication process and its contributions to in situ conservation of genetic resources in Benin. The Scientific World Journal 2012. https://doi.org/ 10.1100/2012/176939

Volpato, G., D. Godínez, and A. Beyra. 2009. Migration and ethnobotanical practices: The case of Tifey among Haitian immigrants in $\mathrm{Cu}$ ba. Human Ecology 37(1): 43-53.

Walther, O. J. 2014. Trade networks in West Africa: A social network approach. The Journal of Modern African Studies 52(2): 179-203.

Wartena, D. 2006. Styles of making a living and ecological change on the Fon and Adja plateaux in South Benin. Wageningen: Wageningen University.

White, D., and R. B. Gramacy. 2012. maptree: Mapping, pruning, and graphing tree models. R package version 1.4-7. https://CRAN.R-project.org/package $=$ maptree

WHO. 2016. International statistical classification of diseases and related health problems 10th Revision. ICD-10 Version for 2016. http:// apps.who.int/classifications/icd10/browse/ 2016/en

Yetein, M. H., L. G. Houessou, T. O. Lougbégnon, O. Teka, and B. Tente. 2013. Ethnobotanical study of medicinal plants used for the treatment of malaria in plateau of Allada, Benin (West Africa). Journal of Ethnopharmacology 146(1): 154-163. 